\title{
Late Jurassic marine vertebrates from Tlaxiaco, Oaxaca State, southern Mexico
}

\author{
Jesús Alvarado-Ortega, Jair Israel Barrientos-Lara, Luis Espinosa-Arrubarrena, \\ and María del Pilar Melgarejo-Damián
}

\begin{abstract}
This paper provides the first geological and paleontological data of Yosobé and La Lobera, two Late Jurassic vertebrate localities; both localities are part of the marine deposits of the Tlaxiaco Basin, near Tlaxiaco, Oaxaca, Mexico. La Lobera may be included in Cerro de Titania, a historical invertebrate locality inaccurately described, whose Oxfordian-Early Kimmeridgian limestone and marl strata are informally known as "Caliza con Cidaris." La Lobera contains the typical "Caliza con Cidaris" fossils and the remains of a single fish attributable to the genus Scheenstia. Yosobé is a fossiliferous outcrop belonging in the Late Jurassic (Kimmeridgian-Tithonian) bituminous shale strata informally known as Sabinal formation. The fossil assemblage from Yosobé includes microfossils, plants, invertebrates, and vertebrates, many of which are totally or partially tridimensionally preserved within nodules. Yosobé is the most important vertebrate locality along the entire Tlaxiaco Basin due to a highly abundant and diverse grouping of fishes and reptiles. The fossil assemblage from Yosobé reported in this paper includes the first and most inclusive regional record of taxa such as the first North American Pleuropholidae fish, the first Mexican Jurassic Planohybodus shark, the most complete specimens of the pycnodont Gyrodus in Mexico and the Caribbean, ichthyosaurs, thalattosuchian crocodyliforms, turtles, and pliosaurids in a single locality at the Western Tethys Sea Domain and the Hispanic Corridor. Present and future descriptive and systematic studies on some fossils from these localities may have important paleobiogeographic and phylogenetic implications worldwide.
\end{abstract}

Jesús Alvarado-Ortega. Instituto de Geología, Universidad Nacional Autónoma de México, Circuito de la Investigación S/N, Ciudad Universitaria, Delegación Coyoacán, Distrito Federal, 04510 México; alvarado@geologia.unam.mx (Corresponding author) Jair Israel Barrientos-Lara. Posgrado en Ciencias Biológicas, Instituto de Geología, Universidad Nacional Autónoma de México, Circuito de la Investigación S/N, Ciudad Universitaria, Delegación Coyoacán, Distrito Federal, 04510 México; j4ir@me.com

Luis Espinosa-Arrubarrena. Instituto de Geología, Universidad Nacional Autónoma de México, Circuito de la Investigación S/N, Ciudad Universitaria, Delegación Coyoacán, Distrito Federal, 04510 México; espinosa@geologia.unam.mx María del Pilar Melgarejo-Damián. Posgrado en Ciencias Biológicas, Instituto de Geología, Universidad 
Nacional Autónoma de México, Circuito de la Investigación S/N, Ciudad Universitaria, Delegación Coyoacán, Distrito Federal, 04510 México; pilar_melgarejo@yahoo.com

Keywords: Jurassic; Reptiles; Fishes; Sabinal formation; Tlaxiaco Basin; Mexico

\section{INTRODUCTION}

The coincidence of two isolated and fortunate events made the preparation of this article possible. In 2008, the first author started an ambitious research program funded by the Universidad Nacional Autónoma de México (UNAM), which aims to recognize the taxonomic diversity of Mesozoic fishes in Mexico. Consequently, the search and recovery of fossil fishes in both new and wellknown localities throughout this country began. The same year, Mr. Jesús Flores Cisneros, a resident of Tlaxiaco, Oaxaca (Figure 1), collected some rock embedded bones in Yosobé, a small valley near his home (also locally spelled Yosobee or Yosove). Shortly thereafter, looking for information on the nature of these bones, Mr. Flores Cisneros met the first author of this paper.

The formal paleontological works in Yosobé began in April 2009 and quickly extended to the nearby areas, including La Lobera (Figure 1). The subsequent field work seasons led to the collection of a large number of fossil marine reptile and fish specimens. Despite the initial uncertainty about the identity of some of these fossils and the age of the bearing rocks in Yosobé, at present, this locality is recognized as an outcrop of a geological unit informally called Sabinal formation (Barrientos-Lara et al., 2013), which was previously documented as a Kimmeridgian-Tithonian deposit within the Tlaxiaco Basin (López-Ticha, 1970, 1985).

The first expedition to the Oxfordian-Early Kimmeridgian marl-limestone strata uncovered in La Lobera, located in the northern area of La Titana Hills and informally named "Caliza con Cidaris" (firstly described as Oxfordian), originally aimed to recognize the paleontological and geological setting in Yosobé and its vicinities. This exercise led to the finding of the first fossil fish in these rocks. Numerous invertebrate fossils from this and other surrounding sites were firstly reported by Felix (1891), who erroneously named this locality

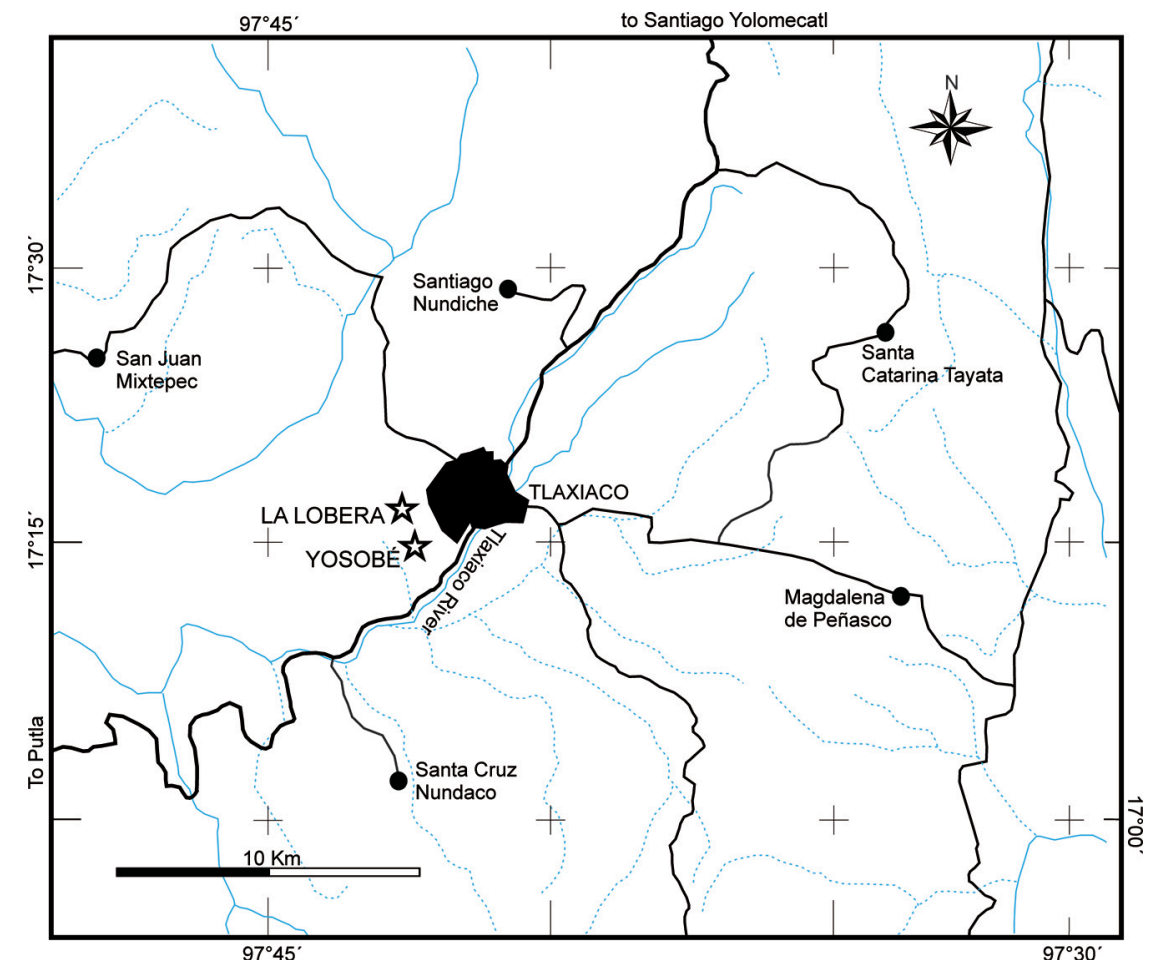

FIGURE 1. Map of Yosobé and La Lobera, near Tlaxiaco, Oaxaca, Mexico. 


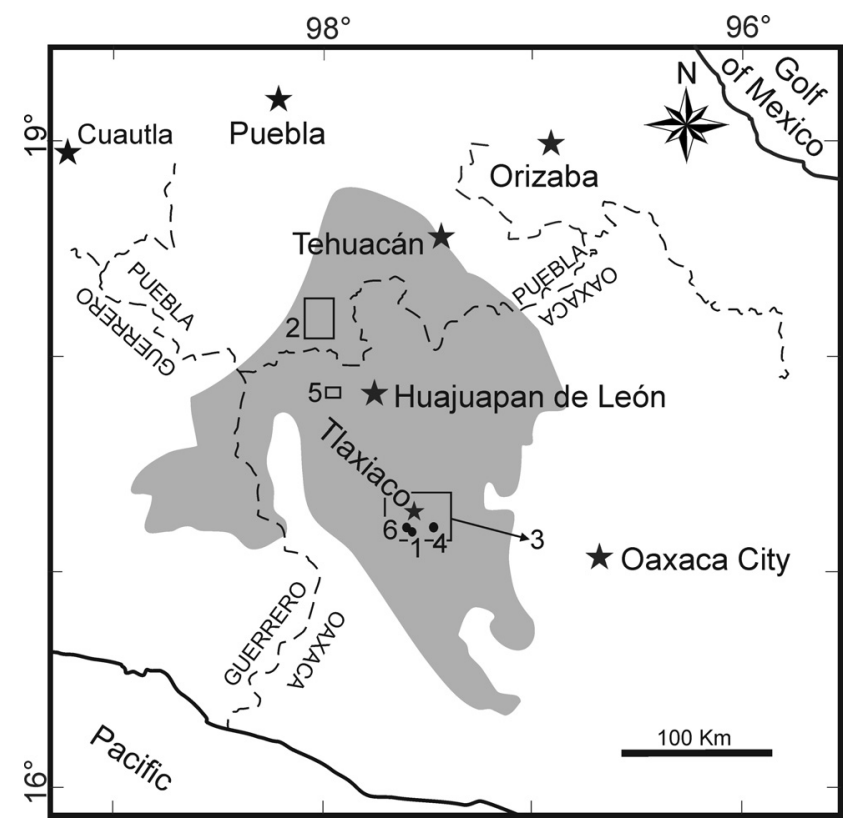

FIGURE 2. Map of the Tlaxiaco Basin and distribution of the vertebrate fossil localities and areas reported before the present manuscript. 1, Cerro de la Virgen; 2, Petlalcingo area; 3, Wieland's area; 4, Amoltepec area; 5, Papalutla; 6; La Lobera; 7 , Yosobé (6 and 7 are new localities reported in the present paper).

"Cerro de Titania" (Titania Hill) (also see Buitrón, 1970), not "Cerro La Titana" as it is formally named today (INEGI, 2000a). In fact, "La Titana" is a group of hills in the southwestern and western of Tlaxiaco town. The invertebrate assemblage of Felix (1891) was identified by the autors in an area of small and shallow ravines locally known as La Lobera; therefore, this name was adopted as the official name for the locality. This distinction permits a controlled and systematic recovery of fossils in La Lobera and avoids possible confusions related to the collection of fossils gathered without a stratigraphic control in "Cerro de Titania."

The previously recovered vertebrate fossils from the Tlaxiaco Basin are extremely rare and their sites of origin are poorly documented (Alvarado-Ortega et al., 2006) (Figure 2). After the restoration of the Mexican Republic at the end of the Maximilian Empire, the Mexican government supported the creation and enrichment of scientific collections. The first vertebrate fossil recovered from the Tlaxiaco Basin, "an ichthyosaur enaliosaurus" collected in the Jurassic coal supplier area of Petlalcingo (a Municipality then part of Oaxaca and currently belonging to Puebla) was apparently sent to Antonio del Castillo in 1870 in order to house it in the Museo Nacional and include it in his "Catálogo Paleontológico de México," a book that was never finished (Morelos-Rodríguez, 2012, p.
191). Unfortunately, this fossil seems to be lost, since it was never reported in further works, and its exact origin remains unknown.

The second fossil fish locality formally documented in Mexico is just a few kilometers East from Yosobé. In this site, called "Cerro de la Virgen," Felix (1891) reported the presence of fish remains in Neocomian strata (Figure 2), which belong to his Otomitla speciosa (Amiiformes) and Belonostomus ornatus (Aspidorynchiformes), as well as possible remains of Thrissops Agassiz, 1833 (Ichthyodectiformes). After Felix (1891), Wieland (1910) launched a paleontological survey in Mexico in 1909 , including a journey along the Eastern region of the Tlaxiaco Basin. He described the marine reptile Plesiosaurus mexicanus based on a single isolated fragment of its rostrum from possibly Neocomian strata of an undocumented locality. This fragment was later recognized as the remains of a possible Jurassic metriorhynchid crocodyliform (Buchy, 2008). Later, Burckardt (1930) found another erroneously documented locality near Amoltepec, Oaxaca, where Kimmeridgian marine strata contain numerous fish remains (still not described). More recently, Ferrusquia-Villafranca and Comas (1988) reported additional Neocomian vertebrate fossil remains in another poorly documented site within the Papalutla region, near Huajuapan de León. These authors identified isolated 
and fragmented remains of a thalattosuchian crocodyliform and an undetermined species of Pliosaurus Owen, 1841. Earlier, Applegate and Comas (1980) had reported the occurrence of the longirostrine fish Belonostomus Agassiz, 1834 in this locality.

More recently, Gutiérrez-Zamora (2011) developed a preliminary report on the vertebrate fossil assemblages from Yosobé, which in part are discussed in this manuscript. This author dated this locality as Neocomian. At present, fossil fish and reptiles recovered from Yosobé and La Lobera constitute the richest and most diverse vertebrate assemblages throughout the Tlaxiaco Basin. The aim of the present manuscript is to provide the first geological and paleontological report of La Lobera and Yosobé as new fossil localities, corroborate the appurtenance of Yosobé to the Late Jurassic marine strata of the Sabinal formation (Kimmeridgian-Tithonian), and give an overview of the Late Jurassic vertebrates so far identified from these localities.

\section{MATERIAL AND METHODS}

To identify the appurtenance of Yosobé and La Lobera within a formal geological unit, the lithologic and paleontological features observed in these fossiliferous sites were compared to those units (formations) already described in Tlaxiaco and surroundings, which are described in the Mexcan Stratigraphic Lexicon (SGM, 2013). The specialized literature cited through the text, and the maps that illustrate this work are those published by the Servicio Geológico Mexicano (SGM, 2000a, 2000b, 2009) and Instituto Nacional de Estadística y Geografía (INEGI, 2000a, 2000b).

All specimens from Yosobé referred and illustrated here were prepared mechanically. The osteological structures were uncovered by means of a stereoscopic microscope, micro air excavators, and needles. When necessary, the specimens were hardened with plexygum. All specimens are deposited in the Colección Nacional de Paleontología (IGM), in the Instituto de Geología, UNAM.

The main goal of this work is to present a general view of the Late Jurassic vertebrate diversity collected from Yosobé and La Lobera. However, it does not represent an exhaustive anatomical, taxonomic, and systematic study. The anatomical abbreviations are described in the captions of the corresponding figures. The taxonomic identity of these fossils was determined by way of updated and meticulous references.

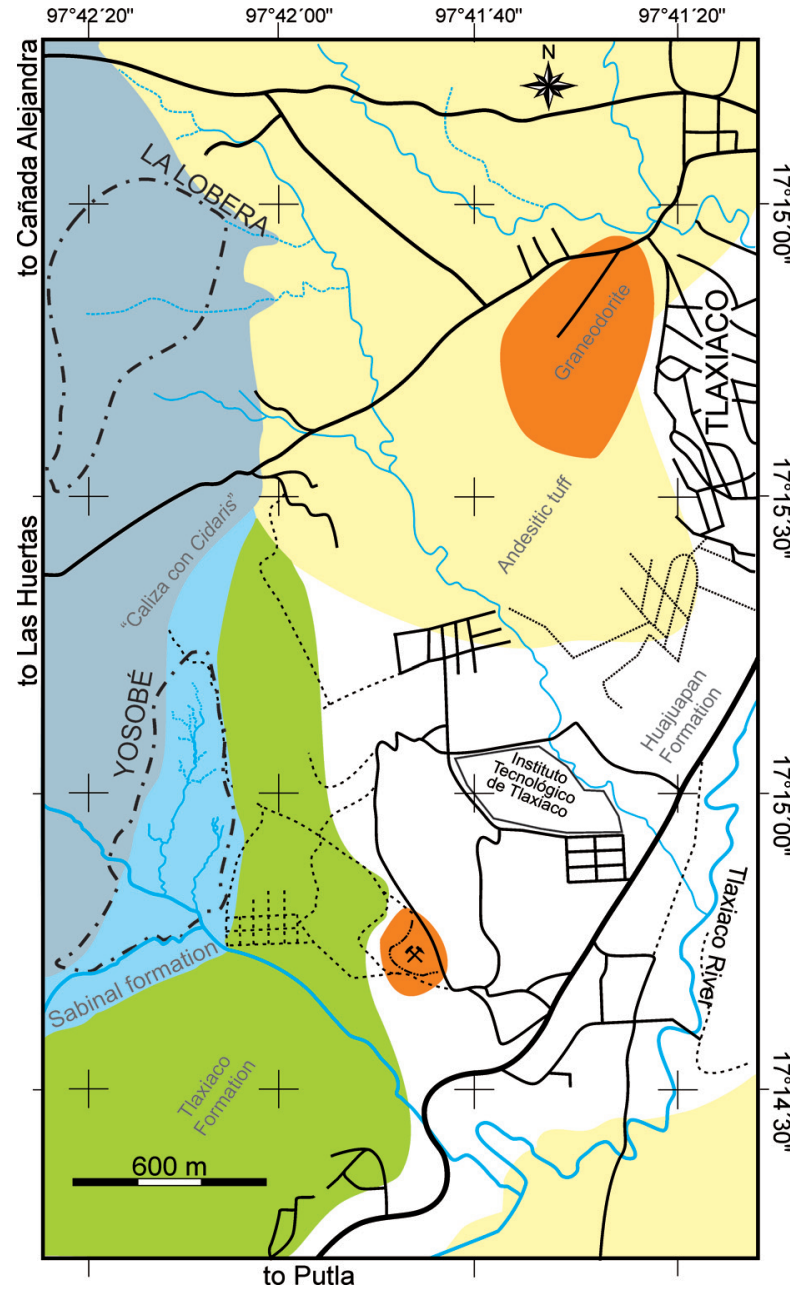

FIGURE 3. Geologic map of Tlaxiaco showing the position and shape Yosobé and La Lobera localities (modified from SGM 2000a, 2000b, 2009).

\section{RESULTS}

\section{Geological Settings}

The fossiliferous site of Yosobé is located 3.5 $\mathrm{km}$ southwest from the downtown of Tlaxiaco, the main village of the homonymous Municipality in the Mixteca region of Oaxaca, southern Mexico (Figures 1-4). This site presents a comma-shaped outcrop, almost $850 \mathrm{~m}$ long and $600 \mathrm{~m}$ wide, placed

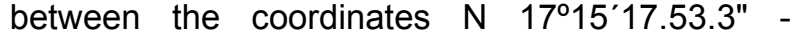

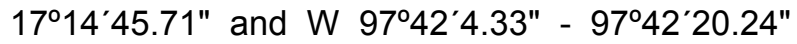
and is located in the bottom of a small valley in the southeastern elevations of La Titana Hills. This valley is locally known as part of "Llano Yosobé."

The Yosobé locality is crossed by three streams that flow southeast into the Tlaxiaco River and erode this valley (Figures 3,4 ). The stream with the NW-SE projection runs along a transgressive fault that divides this locality in two. The geo- 

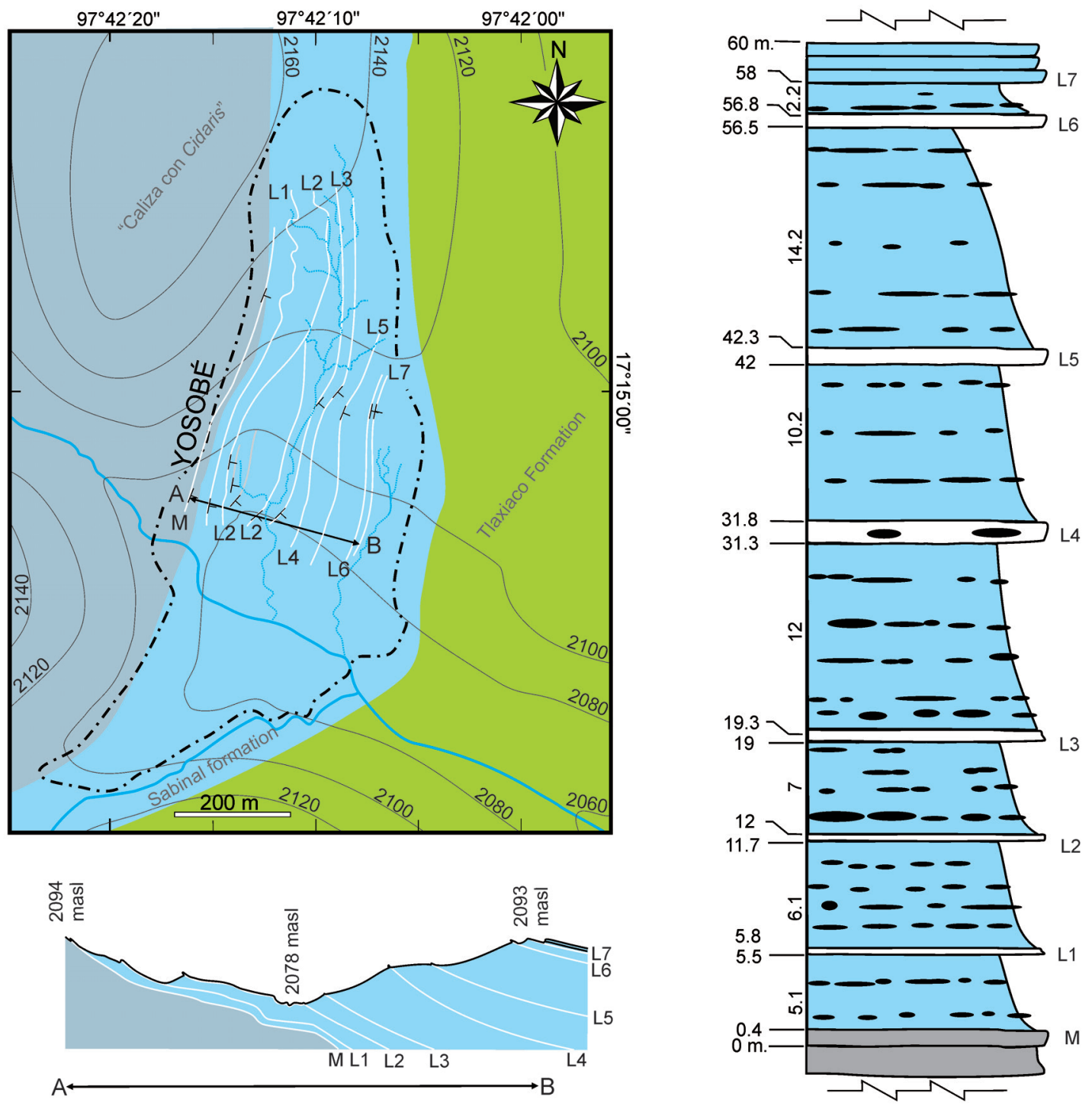

FIGURE 4. Geologic map and lithostratigraphical column of Yosobé. M, Marl stratum; L1-L8, limestone strata; the intermediate strata (L1-L2, L2-L3, ... L7-L8) are the bituminous shales layers that carry the vertebrate assemblage of Yosobé.

logical description of this site is based on its northern part since the original sedimentary structures are strongly and more extensively distorted by this fault in the southern region. The fossiliferous sediments in the northern part of Yosobé comprise an incomplete sloped sequence of at least 60 $m$ thick (Figures 4,5 ), whose base includes a 30$40 \mathrm{~cm}$ thick marl layer that is discovered in the western edge of this locality and bears invertebrates such as trigonids, bivalves, and ammonites. The trigonids do not appear above this level ( $M$ in Figure 4). The overlaying strata include seven relatively thin limestone layers interbedded with thick bituminous shale strata.
These limestones are micritic in texture and their thickness ranges between 30 and $50 \mathrm{~cm}$ (L1L7 in Figure 4). Their color is dark-blue or gray, but turns red when strongly weathered. The bituminous shale strata are millimetric to centimetric, laminated, and their thickness ranges from 5 to 14 $\mathrm{cm}$, their color is dark gray in fresh samples but turns clearer when weathered, and expels a fetid odor when broken (Figure 5). The soft shale sediments are remarkable due to the presence of spherical, ovoid, or amorphous calcareous nodules bearing a few drops of oil, and whose size varies from some centimeters to over a meter. Small crystals of pyrite are sporadically preserved within some nodules. Very few fine sand lenses are pres- 


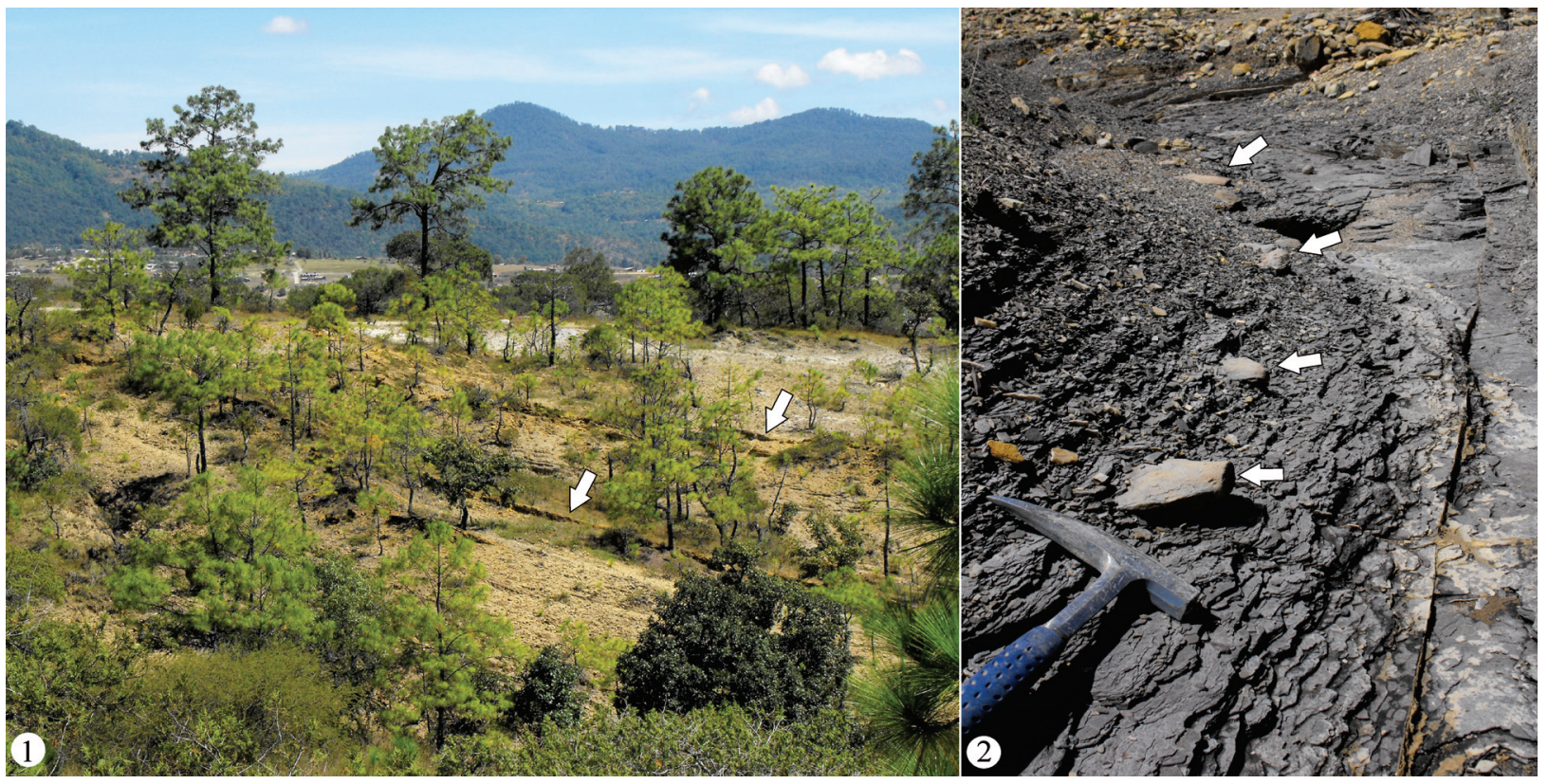

FIGURE 5. Yosobé locality. 1, general view of this locality showing the limestone layers (arrows) and fossil-bearing shale strata (between the arrows), and part of the village of Tlaxiaco in background. 2, bituminous and fossiliferous shale layers at Yosobé with some nodules in situ (arrows).

ent within these shale strata. In the southwestern edge of this locality, dark limestone strata with no interbedding shales are present. These are fossiliferous strata that contain vertebrate material and are covered with soil and cream colored limestone beds, strongly weathered, and with sharp dissolution surfaces. In previous maps, these strata are identified as the base of the Cretaceous sediments (SGM, 2000a, 2000b, 2009).

The slope of strata in the northern part of Yosobé includes a slightly N-E strike and SE dip. The strike and dip directions of these strata show a wide range, between $\mathrm{N} 10-50 \mathrm{E}$ and 20-35SE, respectively; it suggests the presence of buried folds similar to those documented in the limestone bed L2, whose strongly folded surface is exposed in the bottom of the valley along the section A-B traced in Figure 4. The nodules show the original lamination of the shale strata that was probably worn by different compression processes.

The La Lobera locality is situated $1.8 \mathrm{~km}$ from the West of the Tlaxiaco downtown and approximately $1.2 \mathrm{~km}$ from the North of Yosobé (Figures 1, 3). La Lobera, the place of wolves, is a deserted area with poor vegetation and small and shallow ravines, placed between the coordinates $\mathrm{N}$

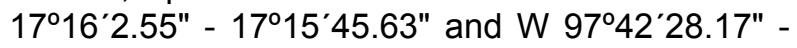
$97^{\circ} 42^{\prime} 08.04^{\prime \prime}$. As noted by Felix (1891), the strata of this locality are constituted by gray marls and limestones interbedded with shales that turn to green or red when weathered. In general, the slopes of strata of Yosobé and La Lobera are similar. However, and unlike Yosobé, La Lobera does not exhibit nodules, and practically all the fossils are invertebrates that represent the taxa previously described by Felix (1891) from his Tithonian "Cerro de Titania" and by Buitrón (1970) as part of the assemblage from the "Caliza con Cidaris" geological unit.

Yosobé and La Lobera are located in the southern area of the Tlaxiaco Basin, a geological depression on the Acatlan-Oaxacan block which ranges from southern Puebla, central and northwestern Oaxaca, to the eastern region of Guerrero (Nieto-Samaniego et al., 2006) (Figure 2). Different Jurassic and Cretaceous geological units were deposited in this basin, most of which are still under informal names.

During the Jurassic, the Tlaxiaco Basin was active, receiving both continental and marine shelf sediments under transgressive and regressive conditions (Rueda-Gaxiola et al., 2007). The Tlaxiaco Basin is at present recognized as the following geological units: 1) The Lower-Middle Jurassic strata once known as the Consuelo Group (Erbern,1956), which lack fossils except for some palynomorphs, today recognized under different informal names, including the Sinemurian-Toarcian carbon carrier sand-silstone-shales and conglomerates (Rosario formation and Conglomerado Pri- 
eto formation, respectively), as well as Pliesbachian -Aalenian quartzitic conglomerates (the Cualac Conglomerate) (e.g., Alencáster, 1963; Meneses-Rocha et al., 1994; Rueda-Gaxiola, 2002). 2) The Middle Jurassic (Bajocian-Callovian) carbonaceous sand-marl-limestone strata and the source of plant and marine invertebrates (Erbern, 1956). These strata belong in to the Tecocoyuncan Group, which includes the Zorrillo, Taberna, Simón, Otatera, and Yucuñuti formations. 3) The Upper Jurassic (Oxfordian) marine units that include the calcarenite-limestone-marl-argillaceous strata formally named Caliza Chimeco Formation (PérezIbargüengoitia et al., 1965) that crops out near Petlalcingo, Puebla; as well as the informally named "Caliza con Cidaris" described in La Titana hills near Tlaxiaco, where numerous marine invertebrate taxa have been reported (e.g., Felix, 1891; Buitrón, 1964, 1970; Alencáster and Buitrón, 1965) suggesting that its age may extend from the Late Callovian to the Early Kimmeridgian (Buitrón,1970, p.155). 4) The Upper Jurassic (KimmeridgianOxfordian) marine bituminous shale informally named as Sabinal formation that crops out in the areas of Tezoatlán, Huajuapan de León, Chalcatongo, Huamuxtitlán, and Tlaxiaco, into Oaxaca (Meneses-Rocha et al., 1994); as well as the marllimetone strata of the Mapache Formation described near Petlalcingo, Puebla (Pérez-lbarguengoitia et al., 1965).

Throughout the Cretaceous, the sedimentation into the Tlaxiaco Basin was mainly of marine nature, including the following units: 5) The Berriasian-Aptian sequence of calcareous breccias-limestone-sandstone-yellow argillaceous limestone informally known as Tlaxiaco formation (OrtegaGonzález and Lambarria-Silva, 1991). 6) The Aptian-Albian anhydrites of the San Juan Teita formation (López-Ticha, 1969). 7) The Albian-Coniacian massive limestones of the Caliza Teposcolula Formation (Salas, 1949), and 8) The TuronianMaastrichthian massive gray-green marls of the Yucunama Formation (Ferrusquía-Villafranca, 1976).

The Cretaceous units described above were deposited beyond the Tlaxiaco Basin, spreading to the East and reaching the Oaxaca Basin (Meneses-Rocha et al., 1994, figure 3). Nevertheless, the marine deposition within the Tlaxiaco Basin ended when Paleogene, and Eocene-Miocene continental sediments and volcanic rocks overlying the Cretaceous Tlaxiaco Basin strata (Martiny et al., 2000).

A comparative study between the fossils collected at La Lobera during this project and those described by Felix (1891) and other authors (e.g., Buitrón, 1970) from "Cerro de Titania" locality is in progress. However, the Cerro de Titania locality is vaguely described as "to the West of Tlaxiaco there are colorful, light gray, greenish, or reddish marl, which are crossed by limonite layers. These marls are dense and strongly carbonated ... for example in Cerro de Titania....where numerous fossils were collected" (Felix, 1891, p. 140); its geological characteristics, forthright position to the West of Tlaxiaco and within the Cerro La Titana, help to recognize the general area referred by Felix, which is today part of the geological unit informally known as "Caliza con Cidaris" (e.g., Buitrón, 1970) that extends beyond the west of Cerro La Titana. Based on this information, the inclusion of La Lobera as part of Cerro de Titania locality and the "Calizas con Cidaris" unity is indisputable.

After the review of the geological units within the Tlaxiaco Basin, the lithological characteristics of the Yosobé strata outlined here are only equivalent to those of the Sabinal formation. Ham-Wong (in Meneses-Rocha et al., 1994, p. 29) described this unit as a sequence of "mudstone and wackestone clay, marl, and dark gray to black bituminous shale strata with abundant calcareous concretions and ammonites"... "arranged in thin laminar layers of 5,10 , and $20 \mathrm{~cm}$, showing abundant light oil impregnations," with 700-1000 m thick sequence crops out in parts in different areas near Tezoatlán, Huajuapan de León, Tlaxiaco, Chalcatongo, and Huamuxtitlán (Bonet in Meneses-Rocha et al., 1994, p. 29). López-Ticha (1969) estimated the Kimmeridgian-Tithonian age of the Sabinal formation based on its ammonite assemblage, which also are an additional element to suggest the stratigraphical correlations between this formation and other Late Jurassic sedimentary units (Burckhardt, 1930), including the Mapache Formation, also within the Tlaxiaco Basin (Alencáster and Buitrón, 1965; Pérez-Ibarguengoitia et al., 1965).

\section{Preservation Types of Fossils from Yosobé}

Practically all the fossils of Yosobé were collected directly from the shale strata. Some of these fossils are preserved within nodules and others were discovered in the contact surfaces of the shale layers. The different types of preservation suggest different diagenetic processes inside and outside of nodules. All the fossils preserved in nodules, including ostracodes (and probably other microfossils) and wood are tridimensional, but most vertebrates and invertebrates are severely damaged. Apart from the nodules, ostracodes are 


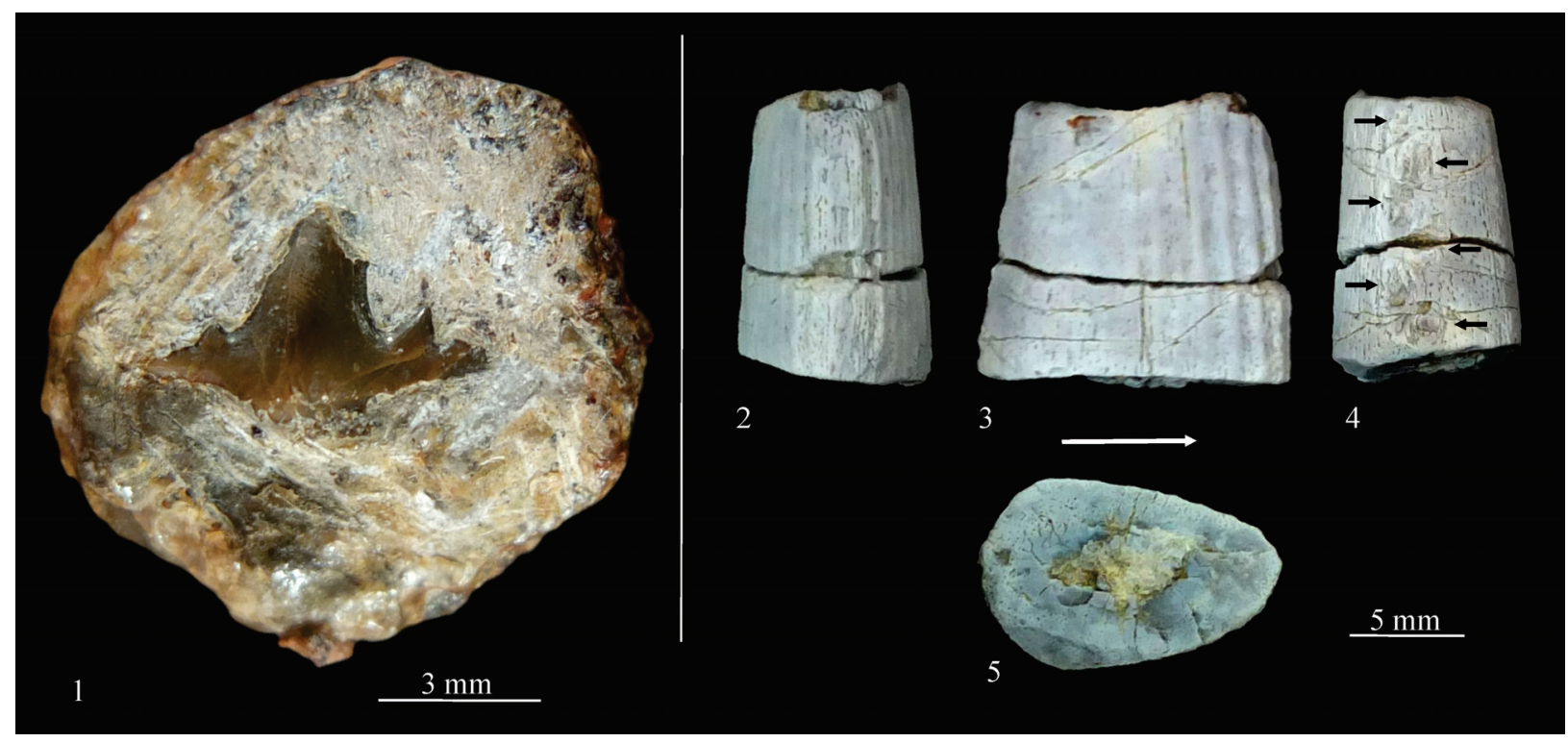

FIGURE 6. Planohybodus sp. from Yosobé; 1, isolated and fragmented tooth, specimen IGM 9316. 2-5, fragment of a dorsal spine in anterior (2), lateral (3), posterior (4), and cross-section (5) views, specimen IGM 9317. Arrow indicates the anterior edge of the predorsal spine.

missing from the surrounding shale. The occurrence of these distinctive kinds of preservation suggests a relatively quick formation of nodules after burial.

The nodules usually encapsulate complete invertebrate carcasses, a process which facilitates a tridimensional preservation and further collection. In contrast, the specimens preserved within the shale strata are strongly compressed, and more or less carbonized. Often, the collection of the fossils becomes difficult because they are buried under high humidity; so the exposition to air causes their quick cracking.

Although the large vertebrates in Yosobé are usually disarticulated, complete or partially complete skeletons have been collected. Usually, the skeleton of the same specimen is preserved by an incomplete nodulation process, in which one or more adjacent nodules contain 3-D structures, but around them, the shale strata include strongly compressed structures of the same individual. Therefore, it is very difficult to obtain complete skeletons, especially when the nodules have been displaced from their original position, regardless the extent of the displacement. Frequently, vertebrate remains are mostly black in color and relatively soft, but when weathered these are white or red colored and are usually more solid.

Remains of wood, ranging between 3 and 5 $\mathrm{cm}$ in diameters, are also 3-D preserved within the nodules; however, these are so strongly carbon- ized that their tissues and taxonomically useful structures are mostly destroyed. Occasionally, very small coal particles are found among the sediments of the shale strata.

\section{Vertebrate Assemblage of Yosobé and La Lobera}

Class Chondrichthyes Huxley, 1880

Order Hybodontiformes Patterson, 1966

Family Hybodontidae Owen, 1846

Genus Planohybodus Rees and Underwood, 2008 Planohybodus sp.

Figure 6.1-5

Type species. Planohybodus peterboroughensis Rees and Underwood, 2008.

Referred material. IGM 9316, isolated imperfect collected in association with a pliosaurid vertebral centrum (Figure 6.1). IGM 9317, isolated fragment of predorsal fin spine (Figure 6.2-5). IGM 9316 comes from the shale strata between levels $M$ and L1 and IGM 9317 from shale layer between L6 and L7 (Figure 4).

Occurrence. Yosobé, Tlaxiaco, Oaxaca. Kimmeridgian-Tithonian shales of the Sabinal formation.

Description. The specimen IGM 9316 is a single isolated tooth with the cusp tip broken and a large part of the root missing. The crown is about $8 \mathrm{~mm}$ and possibly $7 \mathrm{~mm}$ high. The root is remarkably shallow, just about $1 \mathrm{~mm}$ high. The crown includes a cusp and a pair of lateral cuplets on each side. The cusp is high, very broad at the base, slightly 
inclined lingually, and shows a pronounced labiolingually compression (this can be seen in crosssection along the fracture of the tip). The cusplets form triangular structures well separated from each other, with broad bases and of decreasing size. In this series the outer cusplets are particularly small and the cusp could be five times higher than intermediate cusplets. The crown is largely smooth except for some small vertical and almost straight folds present only in the base of the cusp and cuplets. The cutting edge is continuous along the crown; it is weakly sinuous or serrated at the base and both sides of the main cusp. Although it is incomplete, the root was a flat rectangular and porous structure (Figure 6.1).

Specimen IGM 9317 is a fragment of the middle part of a predorsal spine (Figure 6.2-5). In lateral view, this fragment is trapezoidal-shaped, almost as long as high. In cross-section it is drop shaped with straight lateral edges, rounded anterior and posterior edges, and remarkably wider posteriorly (its maximum width $9 \mathrm{~mm}$ near posterior edge). The length of this fragment is $1.4 \mathrm{~cm}$ at the base and $1.2 \mathrm{~cm}$ at the top. The anterior two thirds of both lateral surfaces of the spine are ornamented with seven straight, upward projected, parallel, and evenly spaced ridges. The middle posterior edge bears two rows of denticles that are broken in the specimen. There is no groove between these denticles.

Remarks. Capetta (1987) included Hybodus Agassiz, 1837, Pororhiza Casier, 1969, and Priohybodus Erasmo, 1960, in the family Hybodontidae; however, the recent morphological and systematic review of Hybodus allowed the recognition of other genera, which are Egertonodus Maisey, 1987, Planohybodus Rees and Underwood, 2008, and Secarodus Rees and Underwood, 2008. Maisey $(1987,1989)$ suggested that Hybodus and Egertonodus form the most derived and crown group in the family (Subfamily Hybodontinae) because they develop "high-crowned multicuspid teeth." Later, Rees and Underwood (2008) noted that Planohybodus, Secarodus, and Priohybodus also have high-crowned multicuspid teeth and may comprise a closely related group within Hybodontinae because their teeth are deeply labio-lingually compressed and have cutting borders with serration. The teeth of Priohybodus have well developed serrations that practically go along the entire cutting border while in Planohybodus and Secarodus the serrations are very weak and restricted to the main cusp base. In contrast, teeth of Secarodus and in Priohybodus have divergent cusplets, while in Pla- nohybodus the cusplets are projected in a parallel or convergent manner in relation with the cusp.

The diagnosis of Planohybodus states that this genus differs from other hybodont sharks because the teeth have a high, wide-based, and strongly labio-lingually compressed cusp, its crown has a strongly developed cutting edge and is ornamented with short, simple folds (Rees and Underwood, 2008, p. 126). Later, Bermúdez-Rocha (2009) also noted that this genus has a maximum of two or three pair of cusplets that are remarkably smaller than the cusp, as well as its cutting edge is sinuous or vaguely serrated at the cusp base. Even though it is incomplete, the IGM 9316 shows these characteristics supporting its inclusion in an undetermined species of Planohybodus.

Specimen IGM 9317 shares with the type species of Planohybodus, P. peterboroughensis (and probably with the related species), one of those two combined features of the predorsal spine, which were noted by Rees and Underwood (2008, p. 126 , text-figure 2) as possible diagnostic characters that differentiate this genus from other hybodontid sharks. Both Planohybodus and IGM 9317 lack a groove between the rows of denticles on the posterior spine surface. On the other hand, in IGM 9317 the posterior third surface of the spine is smooth, whereas in Planohybodus the spine is almost entirely ornamented with parallel ridges (the ridges are absent only on a relatively small área on the rear of the upper half of the spine). Although this difference could represent a specific feature, it will require more and better-preserved fossils for better taxonomic identification of these hybodontid sharks from Yosobé.

Hybodontidae is a shark family that lived from the Triassic to the Maastrichtian and had a nearly worldwide distribution (Capetta, 1987). Despite a dubious report on the occurrence of Pennsylvanian and Permian Hybodontid remains from San Salvador Patlanoaya, Puebla, Mexico (Derycke-Khatir et al., 2005), the present is the first concrete finding of Hybodontid sharks in Mexico. Moreover, the occurrence of Planohybodus in Yosobé is interesting because it complements the broken temporal and geographical distribution previously known of this genus. According to Pinheiro et al. (2013, p. 214), this hybodontid was present in the western Tethys Sea Domain in Europe from the Early Jurassic to the Early Cretaceous, it survived until the Late Cretaceous (Santonian and Campanian) in deposits of the Western Interior Seaway in southern USA and Canada. Although this shark inhabited the epicontinental seas of South America during the Early Cre- 


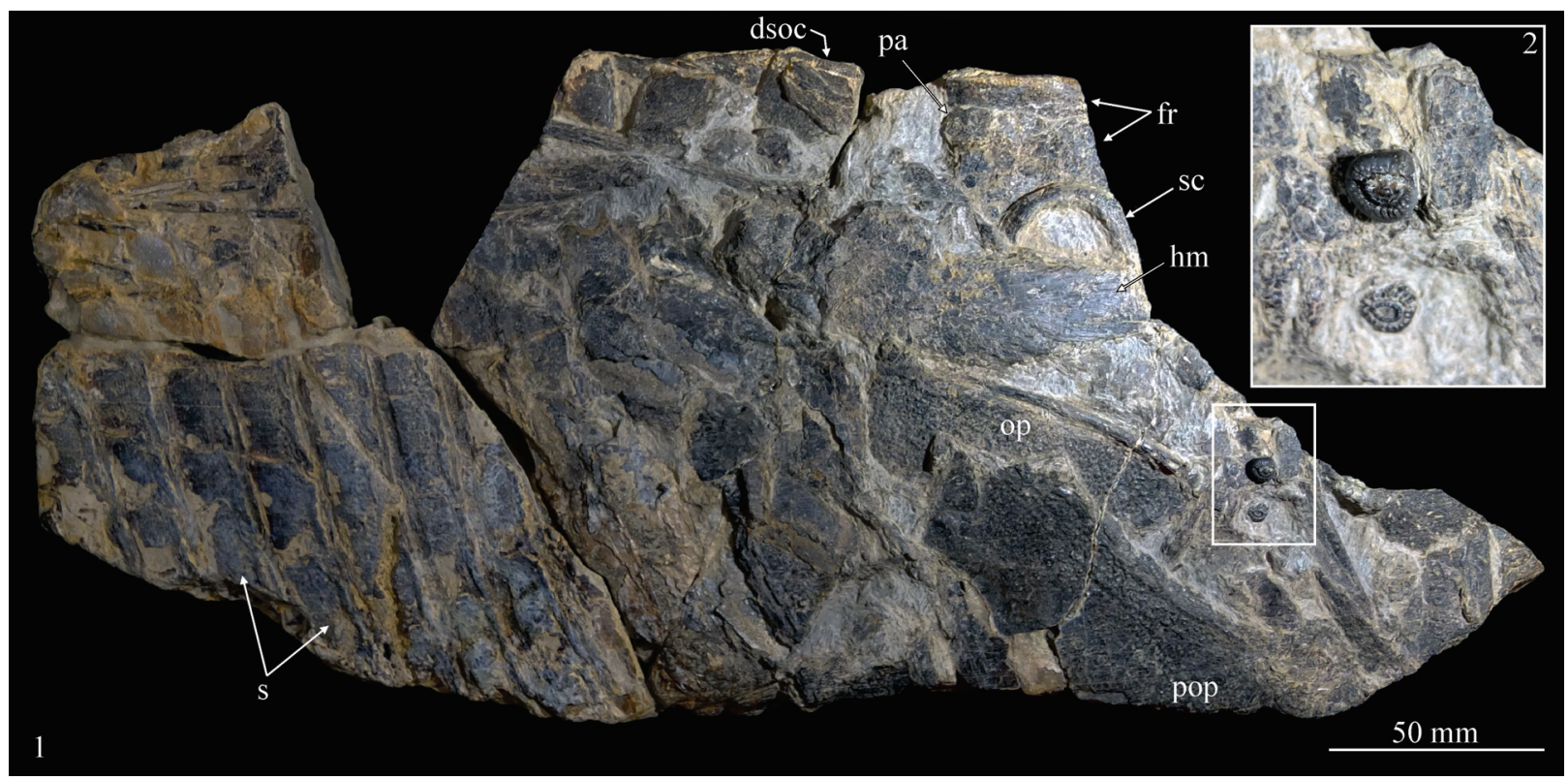

FIGURE 7. Gyrodus sp., specimen IGM 9318 from Yosobé. 1, general view. 2, close up of possible vomerine teeth. Abbreviations: dsoc, dermosupraoccipital; fr, frontal; hm, hyomandibular; op, opercle; pa, parietal; pop, preopercle; s, scale; sc, sclerotic.

taceous; it probably reached this last subcontinent during the Late Jurassic (Cupello et al., 2011). Hence, the presence of Planohybodus in the Kimmerigian shales of Yosobé reveals its possible journey from the Tethys Sea of Europe southward through the Hispanic Corridor, where the marine Sabinal formation strata were deposited.

Class Osteichthyes Huxley, 1880

Division Halecostomi sensu Patterson, 1973

Order Pycnodontiformes Berg, 1937

Family Gyrodontidae Berg, 1940

Genus Gyrodus Agassiz, 1833

Gyrodus sp.

Figure 7

Type species. Gyrodus hexagonus (Blainville, 1818), originally described as Stromateus hexagonus.

Referred material. IGM 9318 (Figure 7), anterior part of the body showing part of the head bones disarticulated. Collected in shale strata between levels L1 and L2 (Figure 4). IGM 9319, a set of scales and disarticulated bones found within a node of $10 \mathrm{~cm}$ diameter from shale strata between levels L4 and L5.

Occurrence. Yosobé, Tlaxiaco, Oaxaca. Kimmeridgian-Tithonian shales of Sabinal formation.

Description. The fragmented head preserved in IGM 9318 is approximately $170 \mathrm{~mm}$ long. Regarding this measurement and the body proportions of Gyrodus published by Lambers (1992, p. 51, 52), where the head length is about $33 \%$ of the standard length, it is possible to suggest that IGM 9318 could reach a standard length close to $500 \mathrm{~mm}$.

The noteworthy characteristic of IGM 9318 is the presence of two isolated oval teeth (probably vomerine teeth), in which the occlusal surface has central papilla surrounded by a mammillated ring, which is surrounded by a strong crenulated ridge; additionally, the largest of these teeth shows a visible groove between its mammilated ring and crenulated ridge (Figure 7). Part of the lateral surface of the skull is visible, showing numerous tubercles ornamenting the external surface of frontals, parietals, and dermosupraoccipital. Numerous tubercles also ornament the surface of the opercle and preopercle. Two well-developed sclerotic bones frame the orbit.

The scales in IGM 9318 and IGM 9319 are rhomboidal; they are well articulated with each other because their anterior border is thick and extends into a ventral spine-like projection that corresponds with a cavity on the dorsal border of the following scale. The surface of scales is ornamented with tubercles that can be randomly distributed or clustered in groups that frequently produce reticular ridges.

Remarks. Gutiérrez-Zamora (2011) considered that the first pycnodont specimens recovered in Yosobé belonged in the genus Mesturus Wagner, 1862. However, the present revision of the scale 
rows of these specimens shows that these pycnodonts do not exhibit "serrated or jagged suture between the scales", which is a diagnostic characteristic of Mesturus (Poyato-Ariza and Wenz, 2002, p. 194).

Poyato-Ariza and Wenz (2002, p. 218) and Kriwet and Schmitz (2005) placed Gyrodus in its own family and regarded it as one of the most basal members of the order Pycnodontiformes. According to Poyato-Ariza and Wenz (2002), the presence of central papilla in the vomerine and prearticular teeth is a unique characteristic (autapomorphy) of Gyrodus, and the fact that IGM 9318 displays this dental characteristic (Figure 7.2) supports the idea of its appurtenance in this genus.

Gyrodus is one of the most commonly cited pycnodont from the marine deposits of Late Jurassic in Europe (Kriwet and Schmitz, 2005). It contains about 32 nominal species, including a large number of probably invalid or synonymous species known just by fragmentary material. At present, only two unquestionable valid species described based on complete and articulated skeletons are known from German localities, including the type species G. hexagonus (Blainville, 1818) from the Kimmeridgian of Solnhofen, and G. circularis Agassiz, 1833, from the Tithonian of Nusplingen (e.g., Lambers, 1991; Poyato-Ariza and Wenz, 2002). The fossils of Gyrodus from Yosobé are important since they include the best preserved fossils external to the eastern Tethys Sea domain, and they potentially represent one of the richest records in America. Therefore, future studies of these fossils will provide new data about the taxonomic diversity and biogeographical history of this genus.

The finding of Gyrodus in Yosobé is in accord and complements the paleobiogeographic pattern of this pycnodont described by Kriwet and Schmitz (2005), which include well documented Middle and Late Jurassic records and discards the questionable Cretaceous records. This geographic-temporal pattern began in the Middle Jurassic and comprises records from deposits within the Northeastern Tethys Sea domain (in Scotland, England, and northern France), records from the beginning of the Late Jurassic, when this genus was more abundant in Europe and then experienced a westward migration beyond the Western Tethys Sea domain as evidenced by the Caribbean remains of Gyrodus found Cuba and Mexico (Gregory, 1923; Dunkle and Maldonado-Koerdell, 1953) and the marine deposits within Southeastern Pacific domains in the western coast of South America (Chile), which finishes at the end of Late Jurassic, when this fish reached the northern Pacific (Siberia and Japan).

Division Ginglymondi sensu Grande, 2010

Order Lepisosteiformes sensu López-Arbarello, 2012

Family unnamed

Genus Scheenstia López-Arbarello and Sferco, 2011

Figure 8.1-4

Referred material. IGM 9320, specimen divided in 22 fragments that include teeth and scales of a single specimen preserved in association with several small oysters (Figure 8.1-4).

Occurrence. La Lobera, Tlaxiaco, Oaxaca. Oxfordian-Early Kimmeridgian marl limestone strata known as the "Caliza con Cidaris" geological unit (Figure 3).

Description. The fragments of IGM 9320 have an uncertain number of scales, many of which are strongly fragmented, partially preserved or complete, as well as a possible fragment of the vomer with some complete teeth preserved. The scales are thick and rhomboidal; some scales range between 40 and $30 \mathrm{~mm}$ in length and height, although some scales are larger. The thick ganoine expands in a continuous and smooth layer with rounded corners. The ganoine is thicker along the borders, so the scales have a shallow central depression. These scales have a wide rounded vertical articulation, their dorsal anterior process is stout, prominent, and sharp, and the ventral anterior process is relatively small, thin, and gently convex.

In the teeth bearing bone fragment recovered, which probably represents part of the vomer, the tooth bases are fused with the bone. These teeth show the tritoral morphology described by Jain (1985), in which a short root supports a crown that is slightly elevated, exceptionally broad and rounded, and practically smooth. Two not emerged and unused teeth preserved in the specimen show a central small sharp protuberance whereas those worn are completely smooth.

Remarks. The IGM 9320 specimen does not show enough characteristics to support its inclusion in the division Ginglymondi sensu Grande (2010). However, it is possible to reach its accurate taxonomical identification within the order Lepisosteiformes, as it was recently defined by LópezArbarello (2012). If characteristics $84,85,86$, and 55 are considered, this specimen shows one of the unambiguous synapomorphies of the order Lepisosteiformes, its scales have two processes forming their rostro-caudal articulation (state 2 of 


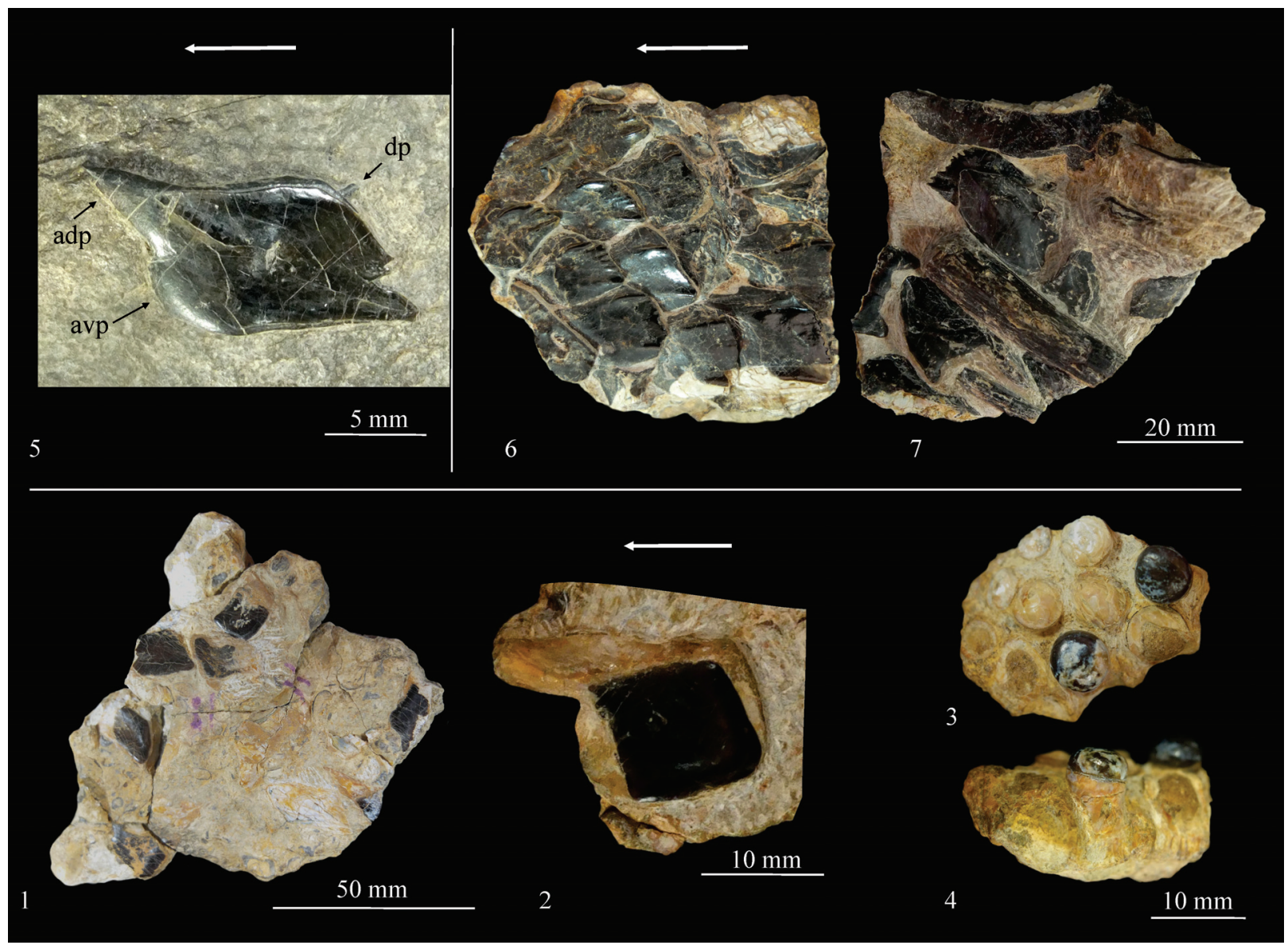

FIGURE 8. Jurassic remains of Ginglymondi fishes from localities near Tlaxiaco. 1-4, Scheenstia sp., specimen IGM 9320 from Tithonian strata of La Lobera, including a group of disarticulated scales (1), isolated scale (2), and a possible fragment of a vomer with teeth (in ventral view and lateral view, 3 and 4, respectively). 5, isolated scale of an undetermined Lepisosteiform described here as Morphotype 1, specimen IGM 9321 from Kimmeridgian strata of Yosobé. 6-7, scales of both sides of the body of an undetermined Lepisosteiform described here as Morphotype 2, specimen IGM 9322 from Kimmeridgian strata of Yosobé. Abbreviations: adp, anterior dorsal process; avp, anterior ventral process; dp, dorsal process; arrows indicate the anterior edge of the scales.

character 86) (also see Cavin et al., 2009). Additionally, the scales of this specimen show a wide rounded vertical articulation; these conditions differ from those present in the lepisosteiformes crown taxa, whose scales have the peg-and-socket vertical articulation reduced or absent in the superfamily Lepisosteoidea (state 1 of character 85 ,) and a strong posteriorly directed spine in the suborder Lepisosteoidei (state 1 of character 84).

According to López-Arbarello (2012, figure 25) and Deesri et al. (in press), there are three genera of lepisosteiformes not in the suborder Lepisosteiodei, Lepidotes Agassiz, 1832, Isanichthys Cavin and Suteethorn, 2006, and Scheenstia. The latter is well diagnosed by the presence of strong tritoral teeth (state 2 of character 55), remarkably similar to the few teeth preserved in the specimen from Yosobé. The characteristics described of IGM 9320 support its inclusion in the genus Scheenstia.

There are not enough characteristics in IGM 9320 to determine its specific identity. As a remark, López-Arbarello (2012, p. 27) noted that the morphological limits and taxonomical relationships between Lepidotes and Scheenstia are not completely resolved, partly because not all the known Lepidotes species were considered in her study.

\section{Family, Genus, and species undetermined}

Note. The ganoid scales of some Ginglymondi taxa show remarkable differences along the trunk of the same specimen (e.g., Gallo and Brito, 2004, p. 253; López-Arbarello, 2012). Two morphotypes of ganoid scales from Yosobé are attributable to the order Lepisosteiformes are described in this section. However, currently, it is impossible to 
make an accurate taxonomic identification and therefore decide whether these scales represent one or two species.

\section{Morphotype 1 \\ Figure 8.5}

Referred material. IGM 9321 (Figure 8.5), isolated scales from shale strata between layers I4-L5 (Figure 4).

Occurrence. Yosobé, Tlaxiaco, Oaxaca. Kimmeridgian-Tithonian shales of the Sabinal formation.

Description. IGM 9321 is an isolated rhomboidal scale, approximately $15 \mathrm{~mm}$ long and $8 \mathrm{~mm}$ high, with rounded dorsal and ventral ends and sharp posterior and anterior tips. The ganoine forms a thin and smooth surface that covers the entire scale except for the anterior and dorsal processes. The dorsal anterior process is stout and sharp whereas the ventral anterior process is gently convex. The dorsal peg (process) is comparatively reduced; it merely forms a small and narrow barlike structure that is projected upward and forward from the posterior half of dorsal scale edge. Among the three serrations present in the posterior end of the scale, the ventral one is the most conspicuous.

Remarks. There is no dispute for the inclusion of IGM 9321 within the Ginglymondi, given that the scales do not have diagnostic characteristics of this Division. As a matter of fact, these scales have characteristics of some ginglymondian subtaxa. Considering some characteristics included in the most comprehensive phylogenetic analysis of this Division hitherto performed (López-Arbarello, 2012 , characters 84,85 , and 86 , respectively) such as the presence of strong posterior directed spines, a peg-and-socket articulation between the scales, and two posterior processes in the longitudinal scale articulation, it is possible to recognize the similarities between these Mexican fossils and some Ginglymondi subtaxa.

The scale preserved in the IGM 9321 specimen shows the unambiguous synapomorphies of the order Lepisosteiformes, the scales have two processes (the anterior ventral and anterior dorsal processes) forming a rostro-caudal or longitudinal articulation (state 2 of character 86 ). This scale shares the reduction of the anterior ventral process (state 1 of character 86) with members of the suborder Lepisosteoidei. This suborder includes the superfamily Lepisosteoidae and other two stem genera, Araripelepidotes Santos, 1990, and Pliodetes Wenz, 1999. In this specimen the scales have a strong posteriorly directed spine (state 1 of characteristic 84), and two small spines located dorsaly, which resemble the arrangement of the spines on the scales of Pliodetes and Araripelepidotes; however, in these genera the arrangement and number of spines vary according to the position of the scales on the body (also see Cavin et al., 2013, figures 20, 21).

Moreover, IGM 9321 presents a scale similar to those in the posterior half of the body of Ararilepidotes, scales with a smooth continuous ganoine surface and barely serrated posterior edge bearing a posteriorly directed spine. IGM 9321 also has a peculiar small dorsal process distinctively located in the posterior half of the scale dorsal edge. In Ararilepidotes there is a well- developed dorsal process (e.g., López-Arbarello, 2012, figure 15 ) and in Lepisosteoidea this process is extremely reduced or absent (state 1 of character 85); however, when it is present the dorsal process is located in the anterior half of the scale dorsal edge in both Ararilepidotes and Lepososteoidea.

\section{Morphotype 2 \\ Figure 8.6-7}

Referred material. IGM 9322, a fragment of the body preserving the scales of both sides of the body (Figure 8.6-7).

Occurrence. Yosobé, Tlaxiaco, Oaxaca. Kimmeridgian-Tithonian shales of the Sabinal formation.

Description. The IGM 9322 specimen is a fragment of the body, about $6 \mathrm{~cm}$ long and $5 \mathrm{~cm}$ high, having part of five scale rows, including well preserved scales, as well as some incomplete bones that were probably part of the pelvic girdle.

The scales are thick and rhomboidal, roughly twice as long as high. These are so strongly overlapped with each other that one scale covers the anterior half surface of the scale of the subsequent row and the rounded and wide dorsal peg of the lower scale of the same row. Each scale bears two anterior processes; the dorsal scale is stout, long, and spine-like, whereas the ventral one is extremely short and rounded. The outer surface of all the scales shows dorsal and ventral thickenings that form strong posteriorly directed spines, which frame a posterior serrated border. The serration is variable along the scale rows; the uppermost scales have few deep serrations (3-4) that are deep and form additional spine-like projections, whereas the lower scales tend to have more numerous (7-8) and less conspicuous serrations. The smooth ganoine layer is also variable in these scales; in the lower scales it is smooth and covers a small posterior area that includes all weak serrations and spines, whereas in the upper scales it barely covers the most superficial area of the strong serration and spines. Small tubercles orna- 
ment the central area of the upper scales whereas the same area is smooth in lower scales.

Remarks. IGM 9322 shows characteristics of some ginglymondi subtaxa, including unambiguous synapomorphies of the order Lepisosteiformes such as the presence of two processes forming a rostro-caudal or longitudinal articulation (state 2 of character 86). It also shows the reduction of the anterior ventral process (state 1 of character 86 ) diagnostic of the suborder Lepisosteoidei. This suborder includes the superfamily Lepisosteoidea and other two stem genera, Araripelepidotes Santos, 1990, and Pliodetes Wenz, 1999. The general shape of the scales of IGM 9322 is similar to the scales of Ararilepidotes, both of them share a serrated posterior edge; however, in this specimen the most ventral and most dorsal serrations are thick and develop spines, while in Ararilepidotes only the ventral spine is developed. Additionally, in IGM 9322 the ganoine surface forms a posterior patch or patches that cover only part of the external surface of the scale which in some cases is ornamented with some tubercles. In contrast, in Ararilepidotes the ganoine surface is smooth and covers the entire external scale surface.

Although the phylogeny of Ginglymondi proposed by López-Arbarello (2012) is a rather extensive approach; it did not include many of the species already described as part of the order "Semionotiformes." This may be the reason why the mixture of characteristics of IGM 9322 seems to be unique when contrasted with those included in that phylogeny. Incidentally, among these nonincluded species there are some Brazilian species, whose scales are somewhat similar to those of IGM 9322, for instance, the Jurassic marine Lepidotes piauhyensis Roxo and Löfgren, 1936, a species previously resolved as a non-lepisosteiform ginglymodian in two phylogenetic analyses (Cavin, 2010, figure 2; Cavin et al., 2013, figure 22). The scales in this species lack tubercles, just as well as two Early Cretaceous and probably freshwater fishes, Lepidotes roxoi Santos, 1953, which show additional superficial grooves (Gallo and Brito, 2004, figure 3), and Lepidotes mawsoni Woodward, 1888, in which the dorsal process of the scales is extremely reduced (Gallo and Brito, 2004, figure 5).

The fossil record of Ginglymondi in Mexico is extremely scarce and before the present work it included only Cretaceous specimens earlier reported as belonging in Lepisosteus Lacépède, 1803, Macrosemiidae, and Tlayuamichin LópezArbarello and Alvarado-Ortega, 2011 (previously reported as Lepidotes Agassiz, 1832 by AlvaradoOrtega et al., 2006; among others). Hence, the specimens IGM 9320, IGM 9321, and IGM 9322, represent the oldest (Late Jurassic) fossils of this division found in the country.

\section{Superdivision Teleostei sensu Arratia, 1999 Order unnamed \\ Family Pleuropholidae Saint-Seine, 1949 Genus and species undetermined} Figure 9

Referred material. IGM 9323 (Figure 9), fragment of the trunk with scattered scales, collected in the shale strata between layers L3 and L4 (Figure 4).

Occurrence. Yosobé, Tlaxiaco, Oaxaca. Kimmeridgian-Tithonian shales of the Sabinal formation.

Description. All the scales preserved in the referred specimen are smooth and evenly thick. These include some ganoid-type and rhomboidalshaped scales, longer than high, with a peg-andsocket type articulation, and no serrated posterior edge. Other scales are rectangular, about 7 or 8 times as high as long, dorsally and ventrally curved, and with a finely serrated posterior edge (Figure 9).

Remarks. Pleuropholidae is a poorly known monophyletic group of basal teleost fishes easily distinguished by a peculiar set of characters, which include the occurrence of a series of high bodyflank scales, a remarkable upturned mouth with curved maxilla, and numerous supra and infraorbital bones (e.g., Patterson, 1973; Lambers, 1992; Brito and Gallo, 2002; Arratia, 2013). Although it is hard to define the position of the scales preserved in the IGM 9323 specimen when alive, it is possible to recognize the extremely high scales as the body-flank scales of a pleuropholid fish. The rhomboidal scales must be those located above and below the latter.

The family Pleuropholidae was erected by Saint-Seine (1949) to include the species of the genus Pleuropholis Egerton, 1958. Afterward (Saint-Seine, 1955), he described two additional genera, Austropleuropholis and Parapleuropholis. More recently, Brito and Gallo (2002) decribed Gondwanapleuropholis as an additional member of this family. Although further findings are required to determine more accurately the taxonomic identity of the pleuropholid fish from Yosobé, IGM 9323 represents the first Pleuropholidae record beyond the Late Jurassic and Early Cretaceous marine deposits on the western Tethys Sea Domain throughout Europe (in England, France, Spain, Italy, and Denmark) and the epicontinental marine deposits in western Gondwana (Brazil, Congo) 


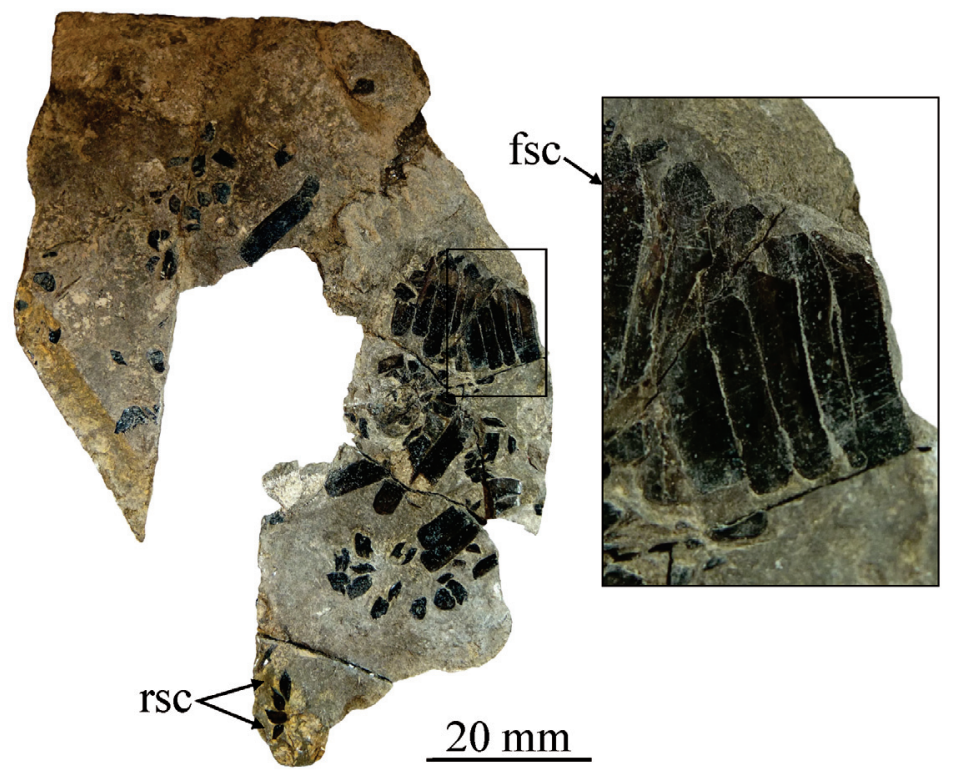

FIGURE 9. Trunk remains of a Pleuropholidae fish, specimen IGM 9323 from Yosobé. Abbreviations: fsc, body-flak scales; rsc, rhomboidal scales.

(e.g., Bravi, 1988; Brito and Gallo, 2002). Hence, this Mexican fossil will contribute to outline the geographical distribution of this group.

Class Sauropsida Goodrich, 1916

Order Crocodyliformes Benton and Clark, 1988

Infraorder Thalattosuchia Fraas, 1901

Family, Genus, and species undetermined

Figure 10.1-3

Referred material. IGM 9324, fragments of two dorsal vertebrae (Figure 10.1-3) from Yosobé. This material was originally preserved within a nodule from the shale layer between limestone strata L4 and L5 (Figure 4).

Occurrence. Yosobé, Tlaxiaco, Oaxaca. Kimmeridgian-Tithonian shales of the Sabinal formation.

Description. Although incomplete, these bones are recognizable as middle dorsal vertebrae of a thalattosuchian crocodyliform. Whereas the posterior vertebra only preserves the anterior half, the anterior is almost complete. The centra are stout and long cylindrical structures, 1.3 times longer than high, and strongly constricted in the middle (in lateral view the ventral and lateral surfaces are concave in a longitudinal direction). In an anteriorposterior view, both intervertebral articular surfaces are ovoid, slightly wider than high (34 versus 32 $\mathrm{mm}$. respectively), and somewhat flattened along the neural canal floor. These vertebrae are weakly amphicelic and both intervertebral articular surfaces are slightly concave.
The neurocentral suture is an irregular and particularly sinuous line located in the upper third of the centrum. The neural arch in the most complete vertebra bears a neural spine that is as long as the centra. The ventral posterior area of the neural spine is projected posteriorly beyond the centrum posterior edge; additionally, this area is wider and laterally carries the flat articular surfaces of the posterior zygapophysis. The anterior zygapophysis is a small process separated from the neural spine and anteriorly projected up and forward. There is no hypapophysis.

Very close to the base of the neural arch and below the anterior zygapophysis is a stout diapophysial process projected laterally from the centrum, whose end must bear the parapophysial process anteriorly and distal process posteriorly. This process is bi-lobed in cross section (Figure 10.3).

Remarks. IGM 9324 is referred to the thalattosuchia crocodyliformes based on its weak amphicelic condition, relatively long neural arch, strong middle constriction, and the up and forward projection of the anterior zygapophysis processes (e.g., Ferrusquía-Villafranca and Comas, 1988; Krebs, 1962). Andrews (1913, p. 161) regarded that the dorsal vertebrae are those in which the parapophysis is wholly or partly borne on the neural arch. Following this criterion, the vertebrae described here is considered dorsal because its 


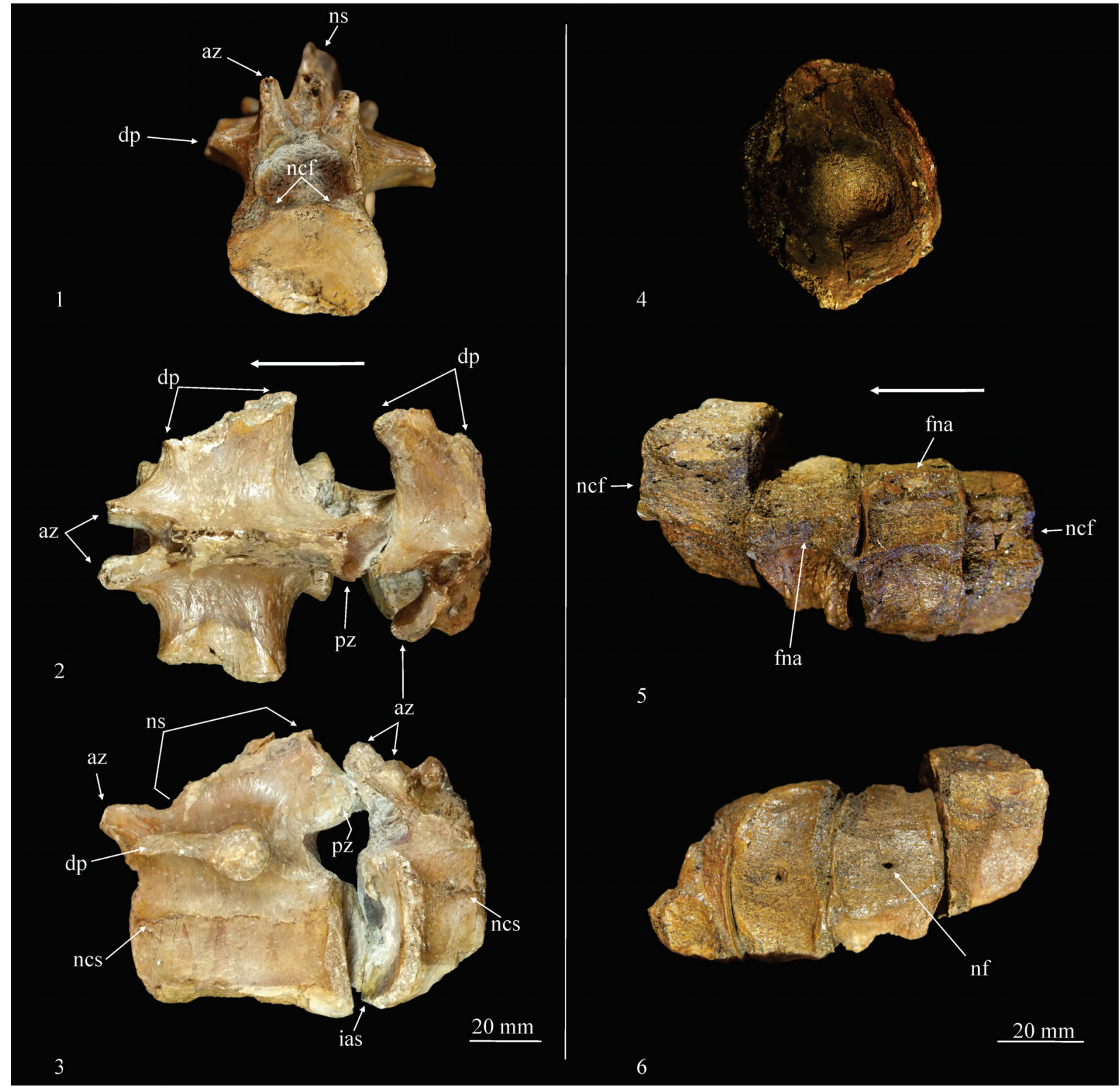

FIGURE 10. Vertebrates of marine reptiles from Yosobé. 1-3, Specimen IGM 9324, undetermined thalattosuchian crocodyliform in anterior (1), dorsal (2), and lateral (3) views. 4-6, Specimen IGM 9325, undetermined ophtalmosaurid ichthyosaur in anterior (4), dorsal (5), and ventral (6) views. In both specimens the arrows show the anterior direction. Abbreviations: dp, diapophysial process; fna, facet for the neural arch; ias, intervertebral articular surfaces; ncf, neural canal floor; ncs, neurocentral suture; nf, nutritive foramen; ns, neural spine; pz, posterior zygapophysis.

paraphophyses are on the base of the neural arches.

The Thalattosuchia are grouped in two monophyletic families, Teleosauridae and Metriorhynchidae (e.g., Mueller-Töwe, 2005). Because of the few differences between the dorsal vertebrae of both families (e.g., Buffetaut and Thierry, 1977, p. 169) and the incompleteness of the vertebrae preserved in IGM 9324, it is not possible to have a more accurate taxonomical determination of this specimen.

Ferrusquía-Villafranca and Comas (1988) described the first thalattosuchian remains found in Mexico, some isolated vertebrae from alleged Neocomian marine strata uncovered in the Papalutla region, Oaxaca. Later, Tithonian metriorhynchids from Puebla and Coahuila, Mexico were described as Geosaurus vignaudi by Frey et al. (2002) and G. 
saltillense by Buchy et al. (2006a). Young and Andrade (2009) and Young et al. (2012) placed these species in the genus Cricosaurus Wagner, 1858 , as C. vignaudi and C. saltillense, respectively. More recently, Buchy et al. (2013) amended the name of the latter, renaming it Cricosaurus saltillensis. Additionally, Buchy et al. (2006b) noted the occurrence of Kimmeridgian and Tithonian teleosaurids and metrorhynchids in localities of Coahuila and Nuevo León, northeastern Mexico. Although the revision of the holotype of Plesiosaurus mexicanus suggests the presence of a metriorhynchid (Buchy, 2008) or else, of Cricosaurus saltillensis (Buchy et al., 2013); additional and comparable fossils from the Tlaxiaco Basin are required to reach a better taxonomical conclusion. Finally, Buchy (2008) reported the finding of skull remains from the Kimmeridgian strata of the La Casita Formation in Nuevo León, Mexico, which she conferred to the genus Dakosaurus Quenstedt, 1856. In the present context, IGM 9324 is the southernmost thalattosuchian fossil known in North America. The possible accurate taxonomical identification of this specimen will be possible after the preparation of other numerous crocodylomorph fossil remains already collected in Yosobé.

Order Ichthyosauria Blainville, 1835

Unranked clade Thunnosauria Montani, 1999

Family Ophthalmosauridae, Baur, 1887

Genus and species undetermined

Figure 10.4-6

Referred material. IGM 9325, four caudal vertebral centra from Yosobé (Figures 10.4-6). It was originally preserved within a nodule from the shale layer between limestone strata L3 and L4 (Figure 4).

Occurrence. Yosobé, Tlaxiaco, Oaxaca. Kimmeridgian-Tithonian shales of the Sabinal formation.

Description. Although strongly eroded, in this specimen four centra from the anterior caudal region are recognized. These are deeply amphicelic centra, ovoid in anterior-posterior view, rectangular laterally, and about 1.8 times higher than long (Figure 10.4-6). The cavities on the anterior and posterior surfaces of these centra are just slightly tilted near the borders and vastly prominent near the center.

In all these centra the floor of neural canal is recognizable, it is practically flat, rectangular in shape, and laterally adjacent to two prominences that represent the facets of the autogenous neural arches. There is a foramen in the middle of the ventral (hemal) surface of these centra. In the ventrolateral area of these centra there is a single ovoid rib-facet that is located in the middle of the transverse process, which is extended through the entire length of the centra.

Remarks. Among marine reptiles, ichthyosaurs are unique in that they have amphicelic and higher than wide vertebra (Andrew, 1910). As the IGM 9325 specimen shows these characteristics, its taxonomic determination as an ichthyosaur is consistent. Unfortunately, the characters of the anterior caudal vertebral centra are poor elements to achieve a more accurate taxonomical identification; however, it is possible to suggest that IGM 9325 belongs to Thunnosauria, an unranked clade erected by Montani (1999) to include Stenopterygius Jaekel, 1904, Ichthyosaurus De la Beche and Conybeare, 1821, and all their younger relatives (McGowan and Motani, 2003).

Fisher et al. (2013, figure 2) noted three major radiation events along the evolution of ichthyosaurs. The Thunnosauria is the only natural group that survived until the Middle Jurassic of those originated from the "Neoichthyosaurian Radiation" occurred at the end of the Triassic. At the beginning of the Middle Jurassic, the Thunnosauria experienced a diversification event, the so called "Ophthalmosaurid Radiation," in which different lineages emerged but apparently disappeared in the same epoch except for the family Ophthalmosauridae, which survived until the Cretaceous. This family includes the subfamilies Ophthalmosaurinae and Platypterygiinae. Ophthalmosaurinae was the most diverse and abundant subfamily in the Middle Jurassic, but began to decline in the Kimmeridgian and disappeared before the beginning of the Cretaceous. Platypterygiinae underwent the third radiation event of ichthyosaurs during the Kimmeridgian, the "Platypterygiine Radiation," from which the groups that survived into the Cretaceous evolved. Fisher et al. (2013) described the only non-Ophtalmosauridae ichthyosaur that survived the Jurassic-Cretaceous boundary as Malawania anachronous. The description of this species was based on a single and incomplete specimen recovered from Hauterivian-Barremian marine strata in Iraq.

The only known specimen of Malawania anachronous lacks the caudal vertebrae, making the morphological comparison between this species and the specimen IGM 9325 impossible. Moreover, the synapomorphies of the Thunnosauria and its subgroups revealed in recent phylogenetic analyses (e.g., Fernández, 2007; Maxwell, 2010; Fisher et al., 2012, 2013; Druckenmiller and Maxwell, 2014) are characters related to the skull, 
limbs, and teeth; since none of these elements is preserved in IGM 9325, also it is not possible to make a comparison between these taxa and this specimen. Therefore the temporal occurrence of IGM 9325 within the Kimmeridgian suggests the inclusion of IGM 9325 within the family Ophtahlmosauridae. Members of this family were extremely diverse, abundant, and reached a worldwide distribution in the Kimmeridgian. In contrast, for now $M$. anachronous is a sole species restricted to a single locality in Iraq that probably represents the last basal and non-opthalmosaurid thunnosaurians, which were considered extinct before the Upper Jurassic (Fisher et al., 2013).

The caudal vertebrae preserved in IGM 9325 show a possible primitive condition also present in Ophthalmosaurinae and Platypterygiinae, in which these vertebrae are 3.5 times or less higher than long. Among the ophthalmosaurids only Ophthalmosaurus incenicus Seeley, 1874, Arthropterygius chrisorum Maxwell, 2010, show the possible homoplasic derived condition that is also present in some non-ophthalmosaurid ichthyosaurs, whose posterior dorsal and anterior caudal vertebrae are 4 or more times higher than long (see Massare et al., 2006; Fischer et al., 2012, appendices 1-4, character 23). In this context, it is not possible to conclude whether IGM 9325 belongs in Ophthalmosaurinae or Platypterygiinae; in consequence it is considered an undetermined member of the Ophthalmosauridae family.

Buchy (2007) acknowledged the occurrence of only two Late Jurassic ophtalmosaurids ichthyosaurs in Mexico, Ophthalmosaurus Seeley, 1874 and Brachypterygius Huene, 1922, both collected in the north of Mexico, far from Yosobé. Although at present it is not feasible to provide new data on the diversity and paleobiogeography of ophtalmosaurids via the study of IGM 9325; this specimen is remarkable because it represents the southernmost record of this group throughout North America to date. It is expected that further work in the preparation of already collected and more complete additional specimens from Yosobé (skull fragments, jaws, and fins) will help to better understand the taxonomical diversity of ichthyosaurs in Mexico and their corresponding implications on other paleontological fields.

\section{Other Vertebrates from Yosobé}

The fossil diversity in the Yosobé locality is much higher than the sample presented here, since a large number of new specimens have already been collected (approximately 50 verte- brate specimens). This assemblage contains additional osteichthyan and reptile taxa whose preparation and precise taxonomical determinations require additional time: numerous ovoid cycloid scales, highly compressed, isolated, and disarticulated small fish bones, and articulated skeletons and isolated bones preserved tridimensionally within nodules, skull fragments, jaws, trunks, fins, and vertebrae in general.

Undoubtedly, among these the most abundant and best preserved correspond to pycnodonts, probably mostly Gyrodus. Liston et al. (2013) started the study of some remains of Pachycormidae fishes from Yosobé. Additionally, some extremely delicate and badly preserved isolated scales of rectangular shape with a height greater than the length, which have been observed as carbonized remains in the shales strata of Yosobé, resemble the typical scales of the longirostrine fishes grouped in the Family Aspidorhynchidae.

Moreover, other four taxa of marine Jurassic reptiles are present in Yosobé. Aside from the crocodylomorphs and ichthyosaurs already referred here, a few plesiosaurid remains from this locality have been preliminarly studied by Barrientos-Lara (2013), who is currently preparing their formal descriptions. In addition, two almost complete shells of possible sea turtles, collected in Yosobé by the two first authors during the 2009 field season, are yet to be prepared. However partially studied to date, the vertebrate fossil assemblage from Yosobé appears to be the most diverse and abundant among the Late Jurassic faunas in the south of North America and the Caribbean.

\section{Non-vertebrate Fossils from Yosobé and La Lobera}

The Jurassic invertebrate assemblage described, illustrated, and identified by Felix (1891, p. 141) from his "Cerro de Titania" was probably partially collected from La Lobera, where we have identified a rich association of invertebrates. Although these fossils are part of a comprehensive taxonomic and biostratigraphic study in progress; it can be noticed that most of them are referable to one of the 14 species described by Felix (1891), some of which have been recently placed in different genera. This assemblage includes the bivalves Myophorella (Trigonia) sologureni, Gryphaea mexicana, Astarte microphyes, the calcispongea Stellispongia (Ceriospongia) bernensis (Étallon in Thurmann and Étallon, 1864), the crinods Angulocrinus (Millericrinus) polyclonos, the brachiopod Animonithyris (Terebratula) dorenbergi, the anne- 
lids Glomerula (Serpula) gordialis (Schlotheim, 1820), and Mucroserpula (Serpula) tricarinata (Sowerby, 1829) [non Goldfuss (1831) as cited by Felix]. The fossil assemblage from La Lobera also contains the echinoids previously reported by Buitrón (1970) from the "Caliza con Cidaris" unit, including Cidaris submarginata and Acrocidaris nobilis Agassiz, 1840.

Specimens of Lima comatulicosta Felix, 1891 are yet to be collected in La Lobera. Fragments of large ostreoids that probably belong in Exogyra Say, 1820, have been collected in this locality; nevertheless, it is not possible to recognize among them any of the three species reported by Felix (1891). This observation suggests that the Cerro de Titania locality is a longer area in relation to the small area defined here as La Lobera. Despite this fact, several specimens of taxa not identified by previous authors have been collected in La Lobera, including an additional species of sea echinoids, remains of gasteropods, undetermined bivalves, and small fragments of corals that may represent a single species. In this site the ammonites are exceptionally scarce and extremely poorly preserved.

In Yosobé, the invertebrates also constitute an abundant and diverse assemblage. The marl thick strata at the bottom of its stratigraphical sequence (Figure 4) bears specimens attributable to a few of the taxa described by Felix (1891), including the bivalves Myophorella sologureni, Astarte microphyes and Gryphaea mexicana. Only the last two of these bivalves are distributed along the upper strata of Yosobé, where numerous large undetermined bivalves of very thin shell appear together with other unidentified bivalves that probably represent the ostreoids Exogyra. In the shale strata of this site there are numerous and diverse ammonites and aptychi that today are part of taxonomical and biostratigraphical study in progress by A.B. Villaseñor-Martínez (Instituto de Geología, UNAM). Finally, in this locality few fragments of corals have been collected, ostracodes and carbonized weed remains also are well preserved within the nodules.

\section{DISCUSSION AND CONCLUSIONS}

The data presented in this study still need to be improved in many ways; however, this first approach achieves the goal to provide a general view on the Late Jurassic marine vertebrate assemblage and their localities of origin within the sediments of the Tlaxiaco Basin. The geological and paleontological significance of these fossils and their implications for local and regional level should be discussed in future studies, which must be accompanied by a meticulous collection of fossils throughout a wider geographical area. Although some tasks are still pending; the future assessment of the geological framework of these fossiliferous deposits should be expanded to a regional level to improve the understanding of the stratigraphic associations of these sedimentary units within the Tlaxiaco Basin, in which data on the invertebrates and microfossils must be included.

Currently, the development of a comprehensive study integrating the geological, systematical, and stratigraphical aspects of the marine strata of the "Caliza con Cidaris," Sabinal formation, and the Tlaxiaco Formation has not yet been performed. Nevertheless, it is possible to avow that La Lobera is an outcrop belonging in the "Caliza con Cidaris" unit since its geographical position, lithology, and fossil assemblage largely correspond with those previously reported in the Cerro de Titania and "Caliza con Cidaris" localities (e.g., Felix, 1891; Buitrón, 1970; Meneses-Rocha et al., 1994).

The presence in La Lobera of invertebrate fossils previously reported in other localities supports its Oxfordian-Early Kimmeridgian age. This observation is consistent with the reports of Buitrón (1970), who suggested that the age of the entire "Caliza con Cidaris" geological unit may range from the Upper Callovian to the Lower Kimmeridgian. Among these fossils occurs Cidaris submarginata, which gives its name to the "Caliza con Cidaris" geological unit. Cidaris submarginata is an Oxfordian species distributed only in Mexico, in the strata of "Caliza con Cidaris" along Puebla and Oaxaca (Burckhardt, 1930; Imlay, 1952; Cárdenas, 1966; López-Ticha, 1969; Buitrón, 1970; Meneses-Rocha et al., 1994) and in the Caliza Chimeco Formation, near Petlalcingo, Puebla (Alecáster and Buitrón, 1965). Acrocidaris nobilis has been identified in marine Upper Oxfordian-Kimmeridgian localities of Switzerland, France, Spain, and southern Mexico (Buitrón, 1970; Baumeister and Leinfelder, 1998; García-González, 2012). Angulocrinus polyclonus has also been reported in Oxfordian localities within Guerrero and Puebla, Mexico (Buitrón, 1990). The small bivalve Gryphaea mexicana, present in La Lobera and Cerro de Titania, is known from the Oxfordian Calizas Chimeco Formation (Alencáster and Buitrón, 1965), in the Middle Oxfordian strata of Jagua Formation, Western Cuba (Pugaczewska, 1978), and in Kimmeridgian deposits of the Malone Formation in Texas and Idaho, USA (Hobbs et al., 1965). Finally, Myo- 
phorella sologureni is present in the Oxfordian fossil assemblages described from Cerro de Titania (Felix, 1891), the Caliza Chimeco Formation (Alencáster and Buitrón, 1965), and in La Lobera and the marl layer at the base of Yosobé ( $M$ in Figure 4).

Prior to the present paper, the only faunistic elements known from the Sabinal formation were some ammonites identified by Cantu-Chapa (in López-Ticha, 1969) and López-Ramos (1981), which include specimens belonging in the genera Subplanites Spath, 1925; Ataxioceras Fontannes, 1879; Idoceras Burckhardt, 1906; Leopoldia Orbigny, 1840; and Neocomites Uhlig, 1905. Although numerous ammonite specimens have been collected in the Yosobé locality, these fossils are part of a taxonomical study in progress by $A$. Villaseñor-Martínez. The recognition of Yosobé as an outcrop of the Sabinal formation is mainly supported by its lithology, which matches the description of this unit published by López-Ticha (1985) and Ham-Wong (in Menese-Rocha et al., 1994), as well as its stratigraphical position above the Kimmeridgian-Tithonian strata belonging in the "Caliza con Cidaris" unit and below the Berriasian-Aptian deposits of the Tlaxiaco Formation.

\section{ACKNOWLEDGMENTS}

We are deeply indebted to Mr. J. F. Cisneros and his nephew A. A. Cruz for their friendship and help during the field seasons. We also thank all the people involved in these works, G. Álvarez-Reyes, R. Hernández-Rivera, C. Nuñez-Alfaro, F. Riquelme, V. Zavaleta-Villarreal, J. Diaz-Cruz, A. Alaniz-Galvan, D. García-Alcántara, G. Velasquillo, P.M. Brito, M.S. Fernández, A. González-Cervantes, M.U. Rosendo-Brito, O. VictorianoTaboada, and I.R. Espinoza-Encinas. This research was supported by Universidad Nacional Autónoma de México by way of the PAPIIT projects IN106011 and IN207314. Additional support to JIB$\mathrm{L}$ was provided by CONACyT Master's degree fellowship.

\section{REFERENCES}

Agassiz, L. 1832. Untersuchungen uber die fossilen Fische der Lias- Formation. Neues Jahrbuch für Mineralogie, Geognosie, Geologie und Petrefaktenkunde, 3:139-149.

Agassiz, J.L.R. 1833-1844. Recherches sur les poissons fossiles. Petitpierre, Neuchâtel et Soleure, Switzerland.
Agassiz, L. 1840. Description des Échinodermes fossiles de la Suisse. Partie 2, Cidarides. Mémoires de la Société des Sciences naturelles Helvetica, 4:1-107.

Andrew, C.W. 1910. A descriptive catalogue of the marine reptiles of the Oxford Clay Part I. British Museum (Natural History), London, England.

Andrews, C.W. 1913. A descriptive catalogue of the marine reptiles of the Oxford Clay, Part II. British Museum (Natural History), London, England.

Alencáster, G. 1963. Pelecípodos del Jurásico Medio del Noroeste de Oaxaca y Noreste de Guerrero. Paleontología Mexicana, 15:1-52.

Alencáster, G. and Buitrón, B.E. 1965. Fauna del Jurásico Superior de la región de Petlalcingo, Estado de Puebla. Paleontología Mexicana, 21, pt. 2:1-53.

Alvarado-Ortega, J., González-Rodríguez, K.A., BlacoPiñón, A., Espinosa-Arrubarrena, L., and OvallesDamián, E. 2006. Mesozoic Osteichthyans of Mexico, p. 69-207. In Vega, F.J., Nyborg, T.G., Perrilliat, M.C., Montellano-Ballesteros, M., Cevallos-Ferriz, S.R.S., and Quiroz-Barroso, S.A. (eds.), Studies on Mexican Paleontology, Volume 24 (Topics on Geobiology). Springer, Dordrecht, the Netherlands.

Applegate, S.P. and Comas, O.R. 1980. Primera ictiofauna del Cretácico Inferior de México, Estado de Oaxaca, p.110. In 5a Convención Geológica Nacional, Resúmenes. Sociedad Geológica Mexicana, México.

Arratia, G. 1999. The monophyly of Teleostei and stemgroup teleosts. Consensus and disagreements, $p$. 265-33. In Arratia, G. and Schultze, H.-P. (eds.), Mesozoic Fishes 2 -Systematics and Fossil Record-. Verlag Dr. F. Pfeil, München.

Arratia, G. 2013. Morphology, taxonomy, and phylogeny of Triassic pholidophorid fishes (Actinopterygii, Teleostei). Journal of Vertebrate Paleontology, 33(suppl.1):1-138.

Barrientos-Lara, J.I. 2013. Determinación taxonómica de los reptiles marinos de la Formación Sabinal (Jurásico Superior Kimmeridgiano-Tithoniano), Tlaxiaco, Oaxaca. Unpublished Bachelor's Thesis, Facultad de Estudios Superiores Iztacala, Universidad Nacional Autónoma de México, D.F., México.

Barrientos-Lara, J.I., Fernández, M.S., and AlvaradoOrtega, J. 2013. Los reptiles marinos de la Formación Sabinal (Jurásico Superior KimmeridgianoTithoniano) Tlaxiaco, Oaxaca, p. 36. In Reynoso, V.H., Oseguera, B., and Flores-Mejía, P. (eds.), Programa y Resúmenes del VIII Congreso Latinoamericano de Paleontología y XIII Congreso Nacional de Paleontología. Sociedad Mexicana de Paleontología, A.C.-Museo Dugés, Universidad de Guanajuato, Guanajuato, México.

Baumeister, J. and Leinfelder, R. 1998. Constructional morphology and Paleoecology significance of three Late Jurassic regular echinoids. Palaeontology, 41(2):203-219.

Baur, G. 1887. On the morphology and origin of the Ichthyopterygia. American Naturalist, 21:837-840. 
Benton, M.J. and Clark, J.M. 1988. Archosaur phylogeny and relationships of the Crocodylia, p. 295-338. In Benton, M.J. (ed.), The phylogeny and classification of the Tetrapods, Vol. 1. Clarendon Press, Oxford, England.

Berg, L.S. 1937. A classification of fish-like vertebrates. Bulletin de l'Académie des Sciences de l'URSS, Classe des Sciences mathématiques et naturelles, 4:1277-1280.

Berg, L.S. 1940. Classification of Fishes Both Recent and Fossil. Trudy Zoologicheskogo Instituta Akademia Nauk SSSR, 5(2):87-517.

Bermúdez-Rochas, D. 2009. New Hybodont shark assemblage from the Early Cretaceous of the Basque-Cantabrian Basin. Geobios 42:675-686.

Blainville, H.M.D. 1818. Poissons fossiles. In Nouveau Dictionnaire d'Histoire naturelle, Déterville, Paris, 27:334-361

Blainville, H.M.D. 1835. Description de quelques éspèces de reptiles de la Californie, précédée de l'analyse d'un systéme générale d'herpétologie et d'amphibiologie. Nouvelles Annales du Muséum d'Historie Naturelle, Paris, 4:233-296.

Bravi, S. 1988. Contributo allo studio del giacimento ad ittioliti di Pietraroja Benevento). I. Pleuropholis decastroi n. sp. (Pisces, Actinopterygii, Pholidophoriformes). Memorie della Società Geologica Italiana, 41:575-586.

Brito, P.M. and Gallo, V. 2002. A new pleuropholid Gondwanapleuropholis longimaxillaris n.g., n.sp. (Actinopterygii: Teleostei) from the Jurassic of north east Brazil. Comptes Rendus Paleovol, 1:697-703.

Buchy, M.-C. 2007. Mesozoic marine reptiles from northeast Mexico: description, systematics, assemblages and palaeobiogeography. Unpublished PhD Thesis, University of Karlsruhe, Germany. Available online digbib.ubka.uni-karlsruhe.de/volltexte/1000007307

Buchy, M.-C. 2008. Reevaluation of the holotype of Plesiosaurus (Polyptychodon) mexicanus Wieland, 1910 from the ?Upper Jurassic of Mexico: a thalattosuchian, not a sauropterygian. Revista Mexicana de Ciencias Geológicas, 25:517-522.

Buchy, M.-C., Young, M.T., and Andrade, M.B. 2013. A new specimen of Cricosaurus saltillensis (Crocodylomorpha: Metriorhynchidae) from the Upper Jurassic of Mexico: evidence for craniofacial convergence within Metriorhynchidae. Oryctos, 10:9-21.

Buchy, M.-C., Frey, E., Stinnesbeck, W., and LópezOliva, J.G. 2006b. An annotated catalogue of the Upper Jurassic (Kimmeridgian and Tithonian) marine reptiles in the collections of the Universidad Autónoma de Nuevo León, Facultad de Ciencias de la Tierra, Linares, México. Oryctos, 6:1-18.

Buchy, M.-C., Vignaud, P., Frey, E., Stinnesbeck, W., and González-González, A.H. 2006a. A new thalattosuchian crocodylifrom from the Tithonian (Upper Jurassic) of northeastern Mexico. Comptes Rendus Palevol, 5:785-794.
Buffetaut, E. and Thierry, J. 1977. Les crocodiliens fossiles du Jurassique Moyen et Supérieur de Bourgogne. Geobios 10(2):151-191.

Buitrón, B.E. 1964. Moluscos del Jurásico Superior de la region de Petlalcingo-Acatlán, Estado de Puebla. Unpublished Bachelor's Thesis, Facultad de Ciencias, Universidad Nacional Autónoma de México, D.F., México.

Buitrón, B.E. 1970. Equinoides del jurásico superior y del Cretacico inferior de Tlaxiaco, Oaxaca, p. 154-163. In Segura, L.R. and Rodríguez-Torres, R. (eds.), Excursión México-Oaxaca, Libro-Guía. Sociedad Geológica Mexicana, México.

Buitrón, B.E. 1990. Presencia de Angulocrinus polyclonus (Felix) en el Oxfordiano del sur de México. Instituto Mexicano del Petróleo, Subdirección de Exploración, Revista, 3(22):19-25.

Burckhardt, C. 1906. La faune jurassique de Mazapil. Boletín del Instituto Geoógico de México, 23:1-216.

Burckhardt, C.1930. Etude synthétique sur le Mesozoïque Mexicain. Mémoire de la Société Paléontologique Suisse, 49-50:1-289.

Cappetta, H. 1987. Chondroichthyes II, Mesozoic and Cenozoic Elasmobranchii, p. 1-193. In Schultze H.P. (ed.), Handbook of Paleoichthyology, v. 3B, Verlag Dr. Gustav Fischer, München.

Cárdenas, V.J. 1966. Contribución al conocimiento geológico de la Mixteca Oaxaqueña. Boletín de Minería y Metalurgía, 38:15-117.

Casier, E. 1969. Addenda aux connaissances sur la faune icthyologique de la Série de Bokungu (Congo). Musée royal de l'Afrique centrale, Tervuren, Belgique, série 8, Sciences Géologiques, 62:1-20.

Cavin, L. 2010. Diversity of Mesozoic semionotiform fishes and the origin of gars (Lepisosteidae). Naturwissenschaften, 97:1035-1040.

Cavin, L. and Suteethorn, V. 2006. A new Semionotiform (Actinopterygii Neopterygii) from Upper JurassicLower Cretaceous Deposits of North-East Thailand, with Comments on the Relationships of Semionotiforms. Palaeontology, 49:339-353.

Cavin, L., Deesri, U., and Suteethorn, V. 2009. The Jurassic and Cretaceous bony fish record (Actinopterygii, Dipnoi) from Thailand, p. 123-137. In Buffetaut, E., Cuny, G., Le Loeuff, J., and Suteethorn, V. (eds.), Late Palaeozoic and Mesozoic Continental Ecosystems of SE Asia. Special Publications, 315, Geological Society London.

Cavin, L., Deesri, U., and Suteethorn, V. 2013. Osteology and relationships of Thaiichthysnov. gen.: a Ginglymodi from the Late Jurassic - Early Cretaceous of Thailand. Palaeontology, 56:183-208.

Cupello, C.D., Bermúdez-Rochas, D., Martill, D. M., and Brito, P.M. 2011. The Hybodontiformes (Chondrichthyes: Elasmobranchii) from the Missão Velha Formation (?Lower Cretaceous) of the Araripe Basin, North-East Brazil. Comptes Rendus Palevol, 11:4147. 
De la Beche, H.T. and Conybeare, W.E. 1821. Notice of the discovery of a new fossil animal, forming a link between Ichthyosaurus and crocodile, together with general remarks on the osteology of Ich-thyosaurus. Transactions of the Geological Society of London, Ser.1(5):559-594.

Deesri, U., Lauprasert, K., Suteethorn V., Wongko, K., and Cavin, $L$. in press. A new species of the ginglymodian Isanichthys Cavin and Suteethorn, 2006, (Actinopterygii, Holostei) from the Late-Jurassic Phu Kradung Formation, northeastern Thailand. Acta Palaeontologica Polonica.

Derycke-Khatir, C., Vachard, D., Dégardin, J.-M., Flores de Dios, A. Buitrón, B., and Hansen, M. 2005. Late Pennsylvanian and Early Permian chondrichthyan microremains from San Salvador Patlanoaya (Puebla, Mexico). Geobios, 38:43-55.

d'Orbigny, A.1840. Paléontologie française; description zoologique et géologique de tous les animaux mollusques et rayonnés fossiles de France. Tome Premier, Terrains Crétacés. Chez L'Auteur, Paris.

Druckenmiller, P.S. and Maxwell, E. 2014. A Middle Jurassic (Bajocian) Ophthalmosaurid (Reptilia, Ichthyosauria) from the Tuxedni Formation, Alaska and the early diversification of the clade. Geological Magazine, 151(1):41-48.

Dunkle, D.H. and Maldonado-Kordell, M. 1953. Notes on some Mesozoic fossil fish remains from Mexico. Journal of the Washington Academy of Science, 43:311-317

Erasmo, G. 1960. Nuovi avanci ittiolitici della "serie di Lugh" in Somalia conservati nel Museo Geologico di Firenze. Palaeontographia Italica, 55(25):1-23.

Erben, H.K. 1956. El jurásico medio y el Calloviano de México. Congreso Geológico Internacional, 20a Sesión, México.

Felix, J. 1891. Versteinerungen aus der mexicanischen Jura- und Kreide-Formation. Palaeontographica, 37:140-194.

Fernández, M.S. 2007. Redescription and phylogenetic position of Caypullisaurus (Ichthyosauria: Ophthalmosauridae). Journal of Paleontology, 81:368-375.

Ferrusquía-Villafranca, I. 1976. Estudios geológico-paleontológicos en la región de la Mixteca. Parte 1: Geología del área Tamazulapan-Teposcolula-Yanhuitlán, -Estado de Oaxaca, México-. Boletín del Instituto de Geología, 97:1-160.

Ferrusquía-Villafranca, I. and Comas, O. 1988. Reptiles marinos mesozoicos en el sureste de México y su significación geológica-paleontológica, p. 104-105. In Convención Geológica Nacional, Resúmenes. Sociedad Geológica Mexicana, México.

Fischer, V., Maisch, M.W., Naish, D., Kosma, R., Liston, J., Joger, U., Fritz, J.K., Pardo-Pérez, J., Tainsh, J., and Appleby, R.M. 2012. New Ophthalmosaurid Ichthyosaurs from the European Lower Cretaceous Demonstrate Extensive Ichthyosaur Survival across the Jurassic-Cretaceous Boundary. PLOS ONE 7(1):e29234.
Fischer, V., Appleby, R.M., Naish, D., Liston, J., Riding J.B., Brindley, S., and Godefroit, P. 2013. A basal thunnosaurian from Iraq reveals disparate phylogenetic origins for Cretaceous ichthyosaurs. Biology Letters, 9(4):20130021.

Fontannes, F. 1879. Descriptions des Ammonites des Calcaires du Château de Crus sol - Ardèche (Zones à Oppelia tenuilobata et Waagnia Beckeri). Savy, Lyon \& Paris.

Fraas, E. 1901. Die Meerkrokodile (Thalattosuchia n. g.) eine neue Sauriergruppe der Juraformation. Jahreshefte des Vereins für vaterländische Naturkunde, Württemberg, 57:409-418.

Frey, E., Buchy, M.-C., Stinnesbeck, W., and LópezOliva, J. G. 2002. Geosaurus vignaudi n. sp. (Crocodylia, Thalattosuchia), first evidence of metriorhynchid crocodilians in the late Jurassic (Tithonian) of central-east Mexico (State of Puebla). Canadian Journal of Earth Sciences, 39:1467-1483.

Gallo, V. and Brito, P.M. 2004. An overview of Brazilian semionotids, p. 253-264. In Arratia, G. and Tintori, A. (eds.), Mesozoic Fishes 3 -Systematics, Paleoenvironments and Biodiversity-. Verlag Dr. Friedrich Pfeil, München, Germany.

García-González, C. 2012. Los equinidos de los arrecifes coralinos del Kimmeridgiense del NE de España. Cidaris, 31:5-29.

Goldfuss, A. 1831. Petrefacta Germaniae, Divisio secunda: Radiariorum reliquiae (Strahlenthiere der Vorwelt).

Goodrich, E.S. 1916. On the classification of the Reptilia. Proceedings of the Royal Society of London $B, 89(615): 261-276$.

Grande, L. 2010. An empirical synthetic pattern study of gars (Lepisosteiformes) and closely related species, based mostly on skeletal anatomy: the resurrection of Holostei. Copeia, 10(suppl. 2, special publication 6):1-871.

Gregory, W.K. 1923. A Jurassic fish fauna from western Cuba, with an arrangement of the families of Holostean ganoid fishes. Bulletin of the American Museum of Natural History, 48:223-242.

Gutiérrez-Zamora, F.T. 2011. Estudio sistemático de los vertebrados fósiles de la Cuenca Tlaxiaco, Oaxaca, México. Informe del Proyecto de Titulación por Apoyo a la Investigación, Facultad de Ciencias, Universidad Nacioal Autónoma de México (unpublished).

Hobbs, W., Briggs, A.B., Wallace, R.E., and Campbell, A. 1965. Geology of the Coeur d'Alene District Shoshone County Idaho: A description of the stratigraphy and structure of one of the world's largest lead-, zinc, and silver- producing mining districts. Geological Survey Professional Paper, 478:1-131.

Huene, F.R.V. 1922. Die Ichthyosaurier des Lias und ihre Zusammenhänge. Verlag von Gebrüder Borntraeger, Berlin. 
Huxley, T.H. 1880. On the application of the laws of evolution to the arrangement of the Vertebrata and more particularly of the Mammalia. Proceedings of the Zoological Society of London, 1880:649-662.

Imlay, R.W. 1952. Correlation of the Jurassic formations of North America exclusive of Canada. Geological Society of America Bulletin, 63(9):953-992.

INEGI 2000a. Carta topográfica Tlaxiaco, E14D34, escala 1: 50 000. Instituto Nacional de Estadística Geografía e Información, México.

INEGI 2000b. Carta topográfica Putla villa de Guerrero E14D44 escala 1: 50 000. Instituto Nacional de Estadística Geografía e Información, México.

Jaekel, O. 1904. Ein neue Darstellung von Ichthyosaurus. Zeitschrift der Deutschen geologischen Gesellschaft, 56:26-34.

Jain, S.J. 1985. Some new observations on Lepidotes maximus (Holostei: Semionotiformes) from the German Upper Jurassic. Journal of the Palaeontological Society of India, 30:18-25.

Krebs, B. 1962. Ein Steneosaurus-Rest aus Oberen Jura von Dielsdorf, Kt. Zurich, Scheiz. Abhandlungen der Schweizerischen Paläontologischen Gesellschaft, 79:1-28.

Kriwet, J. and Schmitz, L. 2005. New insight into the distribution and palaeobiology of the pycnodont fish Gyrodus. Acta Palaeontologica Polonica, 50(1):4956.

Lacépède, B.G.E.1803. Histoire naturelle des poisons 5. Plassan, Paris.

Lambers, P.H. 1991. The Upper Jurassic actinopterygian fish Gyrodus dichactinus Winkler, 1862 (Gyrodus hexagonus [Blainville, 1818]) from Solnhofen, Bavaria and anatomy of the Gyrodus Agassiz. Proceedings of the Koninklijke Nederlandse Akademie von Wetenschappen, 94(4):489-544.

Lambers, P.H. 1992. On the ichthyofauna of the Solnhofen Lithographic Limestone (Upper Jurassic, Germany). Doctoral Proefschrift, Rijksuniversiteit Groningen, Holland.

Liston, J., Maltese, A., and Alvarado-Ortega, J. 2013. 'Fin End of the Wedge': variability of pectoral fin shape in a group supposedly uniformly 'scythe-like', p. 30-31. In Walsh, S., Fraser, N., Brusatte, S., Liston, J., and Carrió, V. (eds.), Programme and Abstracts of 61st Symposium on Vertebrate Palaeontology and Comparative Anatomy \& 22nd Symposium on Palaeontological Preparation and Conservation, Geological Curators' Group. National Museums Scotland and the University of Edinburgh, Scotland.

López-Arbarello, A. 2012. Phylogenetic Interrelationships of Ginglymodian Fishes (Actinopterygii: Neopterygii). PLOS ONE, 7(7):e39370. doi:10.1371/ journal.pone.0039370

López-Arbarello, A. and Alvarado-Ortega, J. 2011. New semionotiform (Neopterygii) from the Tlayúa Quarry (Early Cretaceous, Albian), Mexico. Zootaxa, 2749:124.
López-Arbarello, A. and Sferco, E. 2011. New semionotiform (Actinopterygii, Neopterygii) from the Late Jurassic of Southern Germany. Journal of Systematic Palaeontology, 9(2):197-215.

López-Ticha, D. 1969. Evaluación petrolífera de la Cuenca de Tlaxiaco, Estado de Oaxaca. Seminario sobre exploración petrolera, mesa redonda \#6. Problemas de exploración en áreas posiblemente petrolíferas de la Republica Mexicana. Instituto Mexicano del Petróleo, México.

López-Ticha, D. 1970. Reconocimiento geológico de la Cuenca de Tlaxiaco. Report IGZS-551, Petróleos Mexicanos (unpublished).

López-Ticha, D. 1985, Revisión de la estratigrafía y potencial petrolero de la cuenca de Tlaxiaco. Boletín de la Asociación Mexicana de Geólogos Petroleros, 37:49-92.

López-Ramos, E. 1981. Geología de México. Secretaría de Educación Pública, D.F., México.

Maisey, J.G. 1987. Cranial anatomy of the Lower Jurassic shark Hybodus reticulatus (Chondrichthyes: Elasmobranchii), with comments on hybodontoid systematics. American Museum Novitates, 2878:139.

Maisey, J.G. 1989. Hamiltonichthys mapesi, g. \& sp. nov. (Chondrichthyes; Elasmobranchii), from the Upper Pennsylvanian of Kansas. American Museum Novitates, 2931:1-42.

Martiny, B., Martínez-Serrano, R., Morán-Zenteno, D.J., Macías-Romo, C., and Ayuso, R. 2000. Stratigraphy, geochemistry and tectonic significance of the Oligocene magmatic rocks in western Oaxaca, southern Mexico. Tectonophysics, 318:71-98.

Massare, J.A., Buchholtz, E.A., Kenney, J.M., and Chomat, A.-M. 2006. Vertebral morphology of Ophthalmosaurus natans (Reptilia: Ichthyosauria) from the Jurassic Sundance Formation of Wyoming. Paludicola, 5(4):242-254.

Maxwell, E. E. 2010. Generic reassignment of an Ichthyosaur from the Queen Elizabeth Islands, Northwest Territories, Canada. Journal of Vertebrate Paleontology, 30(2):403-415.

McGowan, C. and Motani, R. 2003. Handbook of Paleoherpetology, Part 8, Ichthyopterygia. Pfeil Verlag, München, Germany.

Meneses-Rocha, J.J., Monroy-Aduelo, M.A, and GómezChavarría, J.C. 1994. Bosquejo paleogeográfico y tectónico del sur de México durante el Mesozoico. Boletín de la Asociación Mexicana de Geólogos Petroleros, 44(2):18-45.

Montani, R. 1999. Phylogeny of the Ichthyopterygia. Journal of Vertebrate Paleontology, 19(3):473-496.

Morelos-Rodríguez, L. 2012. La Geología Mexicana del siglo XIX. Una revision histórica de la obra de Antonio del Castillo, Santiago Ramírez y Mariano Bárcena. Secretaría de Cultura del Estado de Michoacán \& Plaza y Valdés, Mexico.

Mueller-Töwe, I.J. 2005. Phylogenetic relationships of the Thalattosuchia. Zitteliana, Series A, 45:211-213. 
Nieto-Samaniego, A. F., Alaniz-Álvarez, S.A., SilvaRomo, G., Eguiza-Castro, M.H., and MendozaRosales, C.C. 2006. Latest Cretaceous to Miocene deformation events in the eastern Sierra Madre del Sur, Mexico, inferred from the geometry and age of major structures. Geological Society of America Bulletin, 118(112):1868-1882.

Ortega-González, J.V. and Lambarria-Silva, C. 1991. Informe geológico del prospecto Hoja Oaxaca, compilación geológica I.G.R.S. 1129. Petróleos Mexicanos (PEMEX), Coordinación Divisional de Exploración, Gerencia de Exploración Región Sur, Subgerencia de Geología superficial y Geoquímica (unpublished report).

Owen, R. 1841. Odontography. Edited by Owen, R., Part 2. Hippolyte Bailliere, foreign booksellers to the Royal College of Surgeons, London, England.

Owen, R. 1846. Lectures on the comparative anatomy and physiology of the vertebrate animals, delivered at the Royal College of Surgeons of England in 1844 and 1846, Part 1, Fishes. Longman, London, England.

Patterson, C. 1966. British Wealden Sharks. Bulletin of the British Museum (Natural History), Geology, 11(7):283-350.

Patterson, C. 1973. Interrelationships of holosteans, p. 233-305. In Greenwood, P.H., Miles, R., and Patterson, C. (eds.), Interrelationships of Fishes. Academic Press, London.

Pérez-lbargüengoitia, J.M., Hokuto-Castillo, A., and De Cserna, Z. 1965. Estratigrafía y Paleontología del Jurásico Superior de la parte centro meridional del estado de Puebla. Reconocimiento geológico del área de Petlalcingo-Santa Cruz, Municipio de Acatlán, estado de Puebla. Paleontología Mexicana, 21:1-2.

Pinheiro, F., Figueiredo, A.E.Q., Dentzien-Dias, P.C., Fortier, D.C., Schultz, C.I., and Viana, M.S.S. 2013. Planohybodus marki sp. nov., a new fresh-water hybodontid shark from the Early Cretaceous of northeastern Brazil. Cretaceous Research, 41:210-216.

Poyato-Ariza, F.J. and Wenz, S. 2002. A new insight into pycnodontiform fishes. Geodiversitas, 24(1):139-248.

Pugaczewska, H. 1978. Jurassic pelecypods from Cuba. 1978. Acta Palaeontologica Polonica, 23(2):163-186.

Quenstedt, F.A. 1856. Sonst und Jetzt: Populäre Vortäge über Geologie. Laupp, Tübingen, Belgium.

Rees, J. and Underwood, C. 2008. Hybodont sharks of the English Bathonian and Callovian (Middle Jurassic). Palaeontology, 51(1):117-147.

Roxo, M. and Löfgren, A. 1936. Lepidotus piauhyensis, $\mathrm{sp}$. nov. Notas Preliminares e Estudos. Divisão de Geologia e Mineralogia/DNPM, 1:7-12.

Rueda-Gaxiola, J. 2002. Tectonica y paleogeografía durante el Liásico y Jurásico Medio, basada en la información palinoestratigráfica de las cuencas de Huayacocotla-El Alamar, de Tlaxico y Tampico-Misantla. Geos, 22(2):177.
Rueda-Gaxiola, J., De Anda-García, M.A., and PérezSilva, B.S. 2007. Estudio petrológico del Grupo Consuelo (sensu Jiménez Rentería) en Rosario Nuevo, Municipio de Tezoatlán, Oaxaca (Resultados preliminares). Geos, 27(1):54.

Saint-Seine, M.P. 1949. Les Poissons des Calcaires Lithographiques de Cerin (Ain). Nouvelles Archives du Muséum d'Histoire Naturelle de Lyon, 2(I-VII):1357.

Saint-Seine, P. 1955. Poissons fossiles de l'étage de Stanleyville (Congo Belge) - première partie: la faune des argilites et schistes bitumeux. Annales du Musée Royal du Congo Belge, 14:1-126.

Salas, G.P. 1949. Bosquejo geológico de la cuenca sedimentaria de Oaxaca. Boletín de la Asociación Mexicana de Geólogos Petroleros, 1(2):79-156.

Santos, R.S. 1953. Lepidotídeos do Cretáceo da ihla de Itaparica, Estado de Bahia. Ministério da Agricultura, Departamento Nacional da Produção Mineral, Boletim, 145:1-26.

Santos, R.S. 1990. Nova conceituação genérica de Lepidotes tamnurus Agassiz, 1841 (Pisces Semionotiformes). Anais da Academia Brasileira de Ciências, 63:239-250.

Say, Th., 1820. Observations on some species of zoophytes, shells, etc. principally fossil. American Journal of Science, 2(1):34-45.

Schlotheim, E.F.1820. Die Petrefactenkunde auf ihrem jetztigen Standpunkte durch die Beschreibung seiner Sammlung versteinerter und fossiler Überreste des Thier- und Pflanzenreichs der Vorwelt. Becker, Gotha.

Seeley, H.G. 1874. On the pectoral arch and forelimb of Ophthalmosaurus, a new ichthyosaurian genus from the Oxford Clay. Quartery Journal of the Geological Society of London, 30:696-707.

SGM. 2000a. Carta Geológico-Minera, Tlaxiaco E32D34, escala 1:50 000. Servicio Geológico Mexicano y Secretaría de Economía, México.

SGM. 2000b. Carta Geológico-Minera, Oaxaca E14-9, escala 1:250 000. Servicio Geológico Mexicano y Secretaría de Economía, México.

SGM. 2009. Carta Geológico-Minera Estado de Oaxaca, escala 1:1000 000. Servicio Geológico Mexicano y Secretaría de Economía, México.

SGM. 2013. Léxico Estratigráfico de México. Servicio Geológico Mexicano y Secretaría de Economía, Mexico. http://www.sgm.gob.mx/ LexicoEs_ND/ default.html.

Sowerby, J. 1829. The Mineral Conchology of Great Britain, Vol. 6. J. Sowerby, London.

Spath, L.F. 1925. Ammonites and Aptychi, p. 111-164. In Wyllie, N.K. and Smellie, W.R. (eds.), The collection of fossils and rocks from Smaliland, Monograph 7. Geology Department, Hunterian Museum, University of Glasgow. 
Thurmann, J. and Étallon, A. 1864. Lethea Bruntrutana ou études paléontologiques et stratigraphiques sur le Jura bernois et en particulier les environs de Porrentruy - Oeuvre posthume terminée et publiée. Nouveaux mémoires de la Société helvétique des Sciences naturelles, 20:355-500.

Uhlig, V. 1905. Einige bemerkungen über die ammoniten-gattung Hoplites Neumayr. Sitzungsberichte der Kaiserlichen Akademie der Wissenschaften in Wien, Mathematisch-Naturwissenshaftliche Klasse, 114:591-636.

Wagner, A. 1858. Zur Kenntniss der Saurier aus denlithographischen Schiefern. Abhandlungen der Mathemat.-

Physikalischen Classe der Königlich Bayerischen Akademie der Wissenschaften, 8:415-528.

Wagner, A. 1862. Monographie der fossilen Fische aus den lithographischen Schiefern Bayerns. Abhandlungen der kaiserlische Akademie der Wissenchaften, Mathematisch-Naturwissenschaftliche Klasse, 9 (2):277-352.
Wenz, S. 1999. Pliodetes nigeriensis, gen. nov. et. sp. nov., a new semionotid fish from the Lower Cretaceous of Gadoufaoua (Niger Republic): phylogenetic comments, p. 107-120. In Arratia, G. and Schultze, H.-P. (eds.), Mesozoic Fishes 2 -Systematics and Fossil Record-.Verlag Dr. Friedrich Pfeil, München, Germany.

Wieland, G.R. 1910. Plesiosaurus (Polyptychodon) mexicanus Wieland. Parergones del Instituto Geológico de México, 3(6):359-365.

Woodward, A. 1888. Notes on some vertebrate fossils from the Province of Bahia, Brazil, collected by Joseph Mawson. Annals and Magazine of Natural History, London, 2(8):132-136.

Young, M.T. and Andrade, M.B. 2009. What is Geosaurus? Redescription of Geosaurus giganteus (Thalattosuchia: Metriorhynchidae) from the Upper Jurassic of Bayern, Germany. Zoological Journal of the Linnean Society, 157:551-585.

Young, M.T., Brusatte, S.L., Andrade, M.B., Desojo, J.B., Beatty, B.L., Steel, L., Fernández, M.S., Sakamoto, M., Ruiz-Omeñaca, J.I., and Schoch, R.R. 2012. The cranial osteology and feeding ecology of the metriorhynchid crocodylomorph genera Dakosaurus and Plesiosuchus from the Late Jurassic of Europe. PLoS ONE, 7(9):e44985. 